\title{
СОЦІАЛІЗАЦІЯ ОСОБИСТОСТІ ЯК ПРОБЛЕМА МІЖДИСЦИПЛІНАРНИХ ДОСЛІДЖЕНЬ
}

\section{Авраменко О. О., Кравчук Н. П.}

ВСТУП

Модернізація системи освіти в умовах культурного й духовного відродження суспільства потребує звернення до питань забезпечення можливостей для розвитку та самовдосконалення особистості, що підтверджуються основними державними документами, такими як Державні програми «Освіта» (Україна XXI століття), «Діти України», концепція «Сім'я i родинне виховання», Національна стратегія розвитку освіти України у 2013-1021 роках, Закон України «Про дошкільну освіту», Державна цільова програма розвитку дошкільної освіти на період до 2017 р., Базовий компонент дошкільної освіти в Україні. Зміна освітянської парадигми, масштабність і гострота соціальних, економічних, культурних проблем потребують піднесення пріоритету суспільного дошкільного виховання, формування в суспільстві розуміння важливості ранніх етапів життя людини як найвідповідальнішого періоду іiї соціального становлення. Орієнтація сучасної системи освіти спрямована на забезпечення повноцінного соціального розвитку дітей і молоді.

У сучасній науці процес соціалізації визначається як процес засвоєння соціальних стандартів поведінки, ціннісних орієнтацій, гармонізацію взаємозв'язків із новим соціальним середовищем та активне відтворення набутого соціального досвіду у власній діяльності та спілкуванні. Помітний доробок щодо соціально-педагогічних аспектів проблеми оновлення змісту освіти, створення належних умов для соціалізації дітей $\mathrm{i}$ молоді, оптимального їхнього розвитку й виховання належить таким вітчизняним дослідникам, як В. Болгаріна, І. Зверєва, Л. Коваль, Н. Лавриченко, В. Оржеховська, Р. Пріма, О. Савченко, І. Фельдштейн та інші; розкрито соціально-педагогічні аспекти соціалізації (Т. Алєксєєнко, О. Безпалько, В. Болгаріна, Т. Василькова, Ю. Василькова, М. Галагузова, М. Свтух， І. Звєрєва， А. Капська， Л. Коваль， С. Литвиненко， Л. Міщик, А. Рижанова, С. Хлєбік, Л. Штефан та ін.); визначено соціальну компетентність особистості на ранніх етапах соціалізації (Ю. Богинська, О. Караман, О. Кононко, С. Курінна, І. Рогальська-Яблонська, Р. Пріма, С. Семчук та ін.).

У цілій низці досліджень сучасних науковців (Л. Артемова, А. Богуш, Н. Гавриш, Н. Грама, Н. Ватутіна, Т. Жаровцева, Л. Карнаух, О. Кононко, 
T. Поніманська, Н. Рогальська, Т. Степанова, О. Трифонова та ін.) підкреслюється роль дошкільного навчального закладу як інституту соціалізації, у якому створено умови для особистісного й соціального розвитку дитини, ознайомлення із суспільним довкіллям, засвоєння та відтворення нею норм поведінки, соціальних зв'язків і соціального досвіду.

Проведений аналіз наукових джерел підтвердив актуальність проблеми соціалізації дітей і молоді, необхідність вивчення процесів, які проходять на різних етапах становлення особистості.

\section{1. Дослідження феномена соціалізації в соціологічних, психологічних, педагогічних вимірах: історичні інтерпретації}

Докорінне реформування системи освіти в умовах перебудови державності, культурного й духовного відродження України потребує вдосконалення процесу соціального становлення особистості. Соціалізація відбувається як під впливом стихійної взаємодії особистості із соціальним довкіллям, так і за відносно керованого процесу впливу на них соціальних інституцій та агентів соціалізації.

Процес соціалізації для людини є неперервним протягом усього іiі життя. Цього вимагають самі умови іiі життедіяльності. Набуті уявлення про суспільне довкілля збагачуються та поглиблюються, уміння й навички соціальної взаємодії урізноманітнюються та вдосконалюються. Але важливо, щоб усі ці процеси відбувалися послідовно й гармонійно.

Для з'ясування сутності й змісту процесу соціалізації необхідно визначити його місце в процесі життєдіяльності особистості та його роль у формуванні й розвитку особистості.

Потреби дослідження предметної сфери соціалізації особистості, багатогранність і поліаспектність соціалізації як соціального явища зумовлюють необхідність звернення до наявних концепцій, ідей, поглядів і підходів до проблеми дослідження, які відображені в науковій літературі, з'ясування найсуттєвіших теоретикометодологічних положень, які становлять основу сучасної теорії соціального становлення особистості.

Автором терміна «соціалізація» $є$ американський соціолог Франклін Р. Гіддінгс, який у 1887 році в книзі «Теорія соціалізації» використав його в значенні, близькому до сучасного, - «розвиток соціальної природи або характеру індивіда» та «підготовка людського матеріалу до соціального життя» ${ }^{1}$.

Проте звернення до проблематики соціалізації почалося раніше поширення відповідного терміна. Цей процес завжди був у центрі уваги

\footnotetext{
${ }^{1}$ Giddings G. The Theory of Socialization. 1897. №. 8. P. 20-22.
} 
філософів, педагогів і письменників, а в останній третині XIX ст. почав інтенсивно досліджуватися зарубіжними соціологами й соціальними психологами.

Науковцями зроблено спроби визначення сутнісних характеристик соціалізації, виділено основні структурні компоненти, запропоновано підходи до типології й періодизації процесу соціального розвитку особистості, розглянуто особливості соціалізації окремих професійних категорій, соціальних спільнот і вікових груп.

Аналізуючи теоретико-методологічні засади дослідження проблеми соціалізації особистості, варто зазначити, що серед надзвичайно великої кількості теорій і концепцій соціалізації особливої уваги заслуговують декілька теоретичних положень і наукових гіпотез, а саме:

1. Концепція сутності людської природи як єдності її біологічного й соціального компонентів. Прихильники такого підходу (М. Р'юіз, Ч. Меррей, Р. Хернстейн та ін.) посилаються на дані сучасної соціобіології, яка посилено розвивається на Заході з 1975 року, коли іiі засновник Е. Уілсон опублікував книгу «Соціобіологія: новий синтез». Відмінності у визначенні співвідношення зазначених компонентів і субстанціальної пріоритетності визначили як напрями досліджень, так і змістово-суттєві характеристики соціалізації.

2. Концепція соціальної й діяльнісної сутності людини, іiї визначення комплексом суспільних відносин (К. Маркс, Ф. Енгельс та ін.). За цією концепцією, люди в процесі діяльності й через неї змінюють як зовнішні умови свого буття, так і самих себе. Соціальне середовище, що формує людину, водночас $є$ й умовою, і результатом iii діяльності. Свідомість людини та іiі діяльність перебувають у взаємозумовленій єдності. «Сутність людини, - стверджував Маркс, не $є$ абстракт, притаманний окремому індивіду. У своїй дійсності вона $\epsilon$ сукупністю всіх суспільних відносин» ${ }^{2}$.

Для К. Маркса «людська сутність і є істинна спільність людей», що передбачає невичерпну багатоманітність конкретних типів соціальності та способів спілкування людей. У подальшому розвитку зарубіжної філософської думки сутність особистості та процесу іiі соціалізації стали предметом аналізу в багатьох концепціях.

1. Психоаналітична концепція тримірності структури особистості, зв'язана із структурою психіки: «Ід» (несвідомі, ірраціональні реакції та імпульси), «Его» - розумовий рівень, організаційне начало особистості, «Супер-его» (продукт культури, комплекс моральних рис

${ }^{2}$ Марксистско-ленинская диалектика : в 8 кн. Москва : Изд-во Московского унта, 1983. Кн. 1 : Материалистическая диалектика как научная система / под ред. проф. А. П. Шептулина. С. 290-295. 
i норм поведінки). Становлення особистості постає результатом розв'язання протиріч «Ід» $\mathrm{i}$ «Супер-его» ${ }^{3}$.

2. У рамках цієї концепції досліджуються системи психофізіологічних і соціальних механізмів соціалізаційного процесу (П. Бергер, Т. Лукман - інтерналізація, об'єктивація, екстерналізація; Т. Парсонс інтеріоризація, соціальна адаптація; Г. Тард - наслідування, опозиція, адаптація; 3. Фрейд, Е. Фромм - ідентифікація, витіснення, сублімація, регресія, проекція, раціоналізація, реактивна освіта тощо $)^{4}$.

4. Характеристика соціалізації як процесу передавання соціальнокультурного досвіду від покоління до покоління, забезпечення соціальної рівноваги, необхідної передумови відтворення суспільного життя. Найбільш характерними є виділення в цьому процесі «розвитку свідомого життя і створення людської особистості» як основної функції суспільства (Е. Дюркгейм, Т. Парсонс, Г. Спенсер); розгляд соціалізації як безупинного процесу й результату взаємодії індивіда та навколишнього соціального середовища (П. Сорокін); пояснення соціального розвитку за допомогою освоєння соціальних ролей ${ }^{5} ;{ }^{6}$.

5. Виділення певних соціальних інститутів як основних елементів соціалізації, що забезпечують «стилізацію», трансляцію й контроль форм людської поведінки, та їх характеристика: сім’ї (Е. Дюркгейм, О. Конт, П. Сорокін та ін.), економіки (М. Вебер, К. Маркс, Ф. Енгельс та ін.), виховання й освіти (П. Бергер, Т. Лукман та ін.), професійного середовища (Е. Дюркгейм, П. Сорокін та ін.) тощо. Зазначені інститути, на думку Г. Спенсера, як механізми самоорганізації спільної діяльності людей забезпечують перетворення асоціальної за своєю природою людини в соціальну істоту. Розглядаються проблеми результативності соціалізації: концепції соціального «нормального типу» (Г. Зіммель та ін.), аномії (Е. Дюркгейм, Р. Мертон та ін.), десоціалізації (Н. Смелзер та ін.). Так, соціалізована особистість, за визначенням Е. Дюркгейма, це особистість, яка наділена вмінням придушувати індивідуальні інтереси в ім'я суспільних, а виховання є методичною соціалізацією молодого покоління ${ }^{7 ; 8}$.

${ }^{3}$ Фрейд 3. «Я» и «Оно». Труды разных лет / сост. А. Григорашвили ; пер. с нем. Тбилиси : Мерани, 1991. Кн. 1. С. 268-670.

${ }^{4}$ Парсонс Т. Функциональная теория изменения. Американская социологическая мысль. Москва, 1994. С. 448-464.

${ }^{5}$ Смелзер Н. Социология : учебное пособие / пер. с англ. Москва : Феникс, 1998. C. $298-300$.

6 Role Theory: Concepts and Research / ed. by Biddle B.J. \& Thomas E.J. Hungtington (N.J.). Krieger, 1979. P. 45-50.

${ }^{7}$ Смелзер Н. Социология : учебное пособие / пер. с англ. Москва : Феникс, 1998. C. 276. 
6. Характеристика соціалізації з позиції тривалості і стадійності перебігу, виділення ії основних етапів, «життєвих циклів» (Р. Бенедикт, Дж. Мід, 3. Фрейд, Е. Еріксон та ін.), також на засадах концепцій соціальної стратифікації, соціальної мобільності й соціокультурної динаміки (П. Сорокін та ін.); виділення й дослідження низки факторів, що впливають на особистість у процесі соціалізації (Ф. Гіддінгс природно-біологічні, П. Сорокін - космічно-географічні, біофізіологічні, психологічні тощо $)^{9 ; 10}$.

7. Концепція поведінки людини як «суспільно орієнтованих дій», яка розкривається через: а) осмислену орієнтованість на очікування суспільства, б) цілераціональність, в) суб'єктивно цілеспрямовану смислову орієнтацію індивідів (М. Вебер та ін.) та виділення основних форм поведінки, притаманних людині, - дозволених, потрібних, рекомендованих (П. Сорокін та ін. $)^{11}$.

8. Визначення суперечливості характеру функціонування процесу соціалізації як форми і способу соціального розвитку індивіда, регулювання i примусу, обмеження особистісного розвитку (Е. Дюркгейм, 3. Фрейд, Е. Фромм та ін.) на підставі положень про необхідну взаємозумовленість змісту, засобів, форм і методів соціалізаційного впливу й рівня психофізіологічного розвитку особистості. Так, наприклад, за ствердженням Г. Спенсера, «ніяке вчення й ніяка політика не можуть прискорити процес соціального розвитку щодо норми, яка обмежена швидкістю органічних змін людських істот» ${ }^{12}$. Здійснений нами аналіз трактування категорії соціалізації в різноманітних лексикографічних джерелах дав змогу виокремити найістотніші ії ознаки, які формують дефініцію:

- «процес залучення індивіда до системи суспільних відносин, формування його соціального досвіду, становлення й розвитку як цілісної особистості. Соціалізація передбачає взаємодію людини із соціальним оточенням, яка впливає на формування ऑii певних

\footnotetext{
${ }^{8}$ Человек и общество (основы современной цивилизации) : учебная хрестоматия для средней школы. Москва : Геликон, 1992. С. 133.

${ }^{9}$ Гиддингс Ф.Г. Основания социологии. Ленинград : Наука, 1898. С. 5-18.

${ }^{10}$ Сорокин П.А. Социокультурная динамика и эволюционизм. Американская соичилогическая мысль. Москва, 1996. С. 372-392.

11 Вебер М. О некоторых категориях понимающей социологии. Западноевропейская социология XIX - начала XX веков. Москва : Наука, 1996. C. 491-507.

12 Дюркгейм Э. Метод социологии. Западноевропейская сочиология XIX-начала ХХ веков. Москва, 1996. С. 256-304.
} 
соціальних якостей і рис, на активне засвоєння й відтворення нею системи суспільних зв'язків» ${ }^{13}$;

- «розвиток людини протягом усього життя у процесі засвоєння та відтворення культури суспільства» ${ }^{14}$;

- «процес включення людини в соціальну практику, набуття нею соціальних якостей, засвоєння суспільного досвіду й реалізація власної сутності через виконання певних ролей у практичній діяльності» 15 ;

- «процес, який уможливлює існування суспільства й передачу його культури від покоління до покоління» ${ }^{16}$;

- відбувається через наслідування, навіювання, передачу досвіду й набуття різноманітних вражень у життєвих ситуаціях ${ }^{17}$;

- процес засвоєння індивідом зразків поведінки, соціальних норм і цінностей, необхідних для його успішного функціонування в певному суспільстві ${ }^{18}$;

- процес засвоєння індивідом зразків поведінки, психологічних механізмів, соціальних норм і цінностей, необхідних для успішного функціонування в певному суспільстві» ${ }^{19}$;

- процес засвоєння та активного використання індивідом суспільного досвіду (система знань, норм, цінностей), що здійснюється в спілкуванні й повсякденній діяльності; допомагає людині функціонувати як повноправному члену суспільства» ${ }^{20}$;

- процес входження індивіда в суспільство, активного засвоєння ним соціального досвіду, соціальних ролей, норм, цінностей, необхідних для успішної життєдіяльності в цьому суспільстві ${ }^{21}$.

${ }^{13}$ Гончаренко С.У. Український педагогічний словник. Київ : Либідь, 1997. С. 314.

${ }^{14}$ Педагогический энциклопедический словарь / гл. ред. Б.М. Бим-Бад ; ред. кол. : М.М. Безруких, В.А. Болотов, Л.С. Глебова и др. Москва : Большая рос. энциклопедия, 2002. C. 266.

${ }^{15}$ Словарь социального педагога и социального работника / под ред. И.И. Калачевой, Я.Л. Коломинского, А.И. Левко. 2-е изд. Минск : БелЭн, 2003. С. 180-181.

${ }^{16}$ Соціологія: терміни, поняття, персоналії : навчальний словник-довідник / уклад. : В.М. Піча, Ю.В. Піча, Н.М. Хома та ін. ; за заг. ред. В.М. Піча. Київ : Каравела; Львів : Новий Світ-2000, 2002. С. 341.

17 Педагогический энциклопедический словарь / гл. ред. Б.М. Бим-Бад ; ред. кол.: М.М. Безруких, В.А. Болотов, Л.С. Глебова и др. Москва : Большая рос. энциклопедия, 2002. С. 301.

${ }^{18}$ Коджаспирова Г.М., Коджаспиров А.Ю. Педагогический словарь : для студ. высш. и сред. пед. учеб. заведений. Москва : Академия, 2000. С. 83.

19 Энциклопедический социологический словарь / общ. ред. Г.В. Осипова ; ред.сост. А.В. Кабыща. Москва : ИСПИРАН, 1995. С. 684.

${ }^{20}$ Дошкільна освіта : словник-довідник : понад 1000 термінів, понять та назв / упор. К.Л. Крутій, О.О. Фунтікова. Запоріжжя : ТОВ «ЛІПС» ЛТД, 2010. С. 247.

21 Орбан-Лембрик Л.Е. Психологія професійної комунікації : навчальний посібник. Чернівці : Книги XXI, 2010. С. 408. 
Аналогічні визначення соціалізації даються й в інших працях і виданнях. Виходячи 3 наведених вище дефініцій і думок інших авторів, можна вважати, що соціалізація - це:

- тип соціального процесу;

- процес засвоєння цінностей, норм, правил;

- оволодіння соціальними ролями і функціями;

- оволодіння знаннями, навичками соціальної поведінки, соціальної дії, взаємодії;

- засвоєння правил взаємодії у соціальних відносинах;

- вироблення соціальних ціннісних орієнтацій;

- оволодіння системою механізмів, форм i методів функціонування особистості в суспільстві;

- у сукупності - це процес становлення людини як особистості, здатної здійснювати життєдіяльність у суспільстві.

Аналіз концепцій і теорій соціалізації особистості дає можливість відзначити, що концептуальні положення, підходи та ідеї зарубіжних дослідників зробили вагомий внесок у розроблення й дослідження проблем соціалізації, сприяли їх становленню як самостійного наукового напряму.

Згідно з теорією С. Гессена, процес соціалізації містить три основні етапи:

1. Дошкільний період (період довільного розвитку), де переважає ігрова діяльність дитини. Процес соціалізації залежить здебільшого від сім’ї та взаємин у системі «батьки - діти».

2. Шкільний період (період активного пізнання законів і вимог життя). Процес соціалізації в цей період залежить здебільшого від діяльності навчально-виховного закладу й оточення дитини.

3. Постшкільний період (період завершення формування особистості, що характеризується інтенсивною самоосвітою, самовдосконаленням, сформованістю позиції та світогляду особистості). Процес соціалізації в цей період залежить від усвідомлення власного «Я» та оточення особистості ${ }^{22}$.

У формуванні світогляду особистості важливу роль відіграє соціальне й культурне середовище, яке оточує дитину, а також особливе значення його для всіх дітей із раннього віку, а не тільки на третьому ступені розвитку. Відомий французький учений Г. Тард трактує процес соціалізації як включення індивіда в націю, у народ. Суспільство Г. Тард характеризує як групу людей, однаково вихованих,

22 Авраменко О.О. Соціалізація особистості в контексті вітчизняних та зарубіжних науково-педагогічних досліджень. Вісник Черкаського університету. Серія «Педагогічні науки». Черкаси, 2015. № 10 (343). С. 7-13. 
що взаємовпливають одне на одного. Соціалізація розуміється ним як «багатобічна одноманітність, до якої йде суспільство» ${ }^{23}$.

Соціальні основи соціалізації особистості та цього процесу розглянуті в публікаціях Н. Смелзера. Автор наголошує, що для успішної соціалізації необхідна дія трьох чинників:

1) очікування;

2) зміни поведінки;

3) прагнення відповідати цим очікуванням.

Процес формування особистості, на його думку, відбувається на трьох різних стадіях:

1) стадії наслідування й копіювання дітьми поведінки дорослих;

2) ігрової стадії, коли діти усвідомлюють поведінку як виконання ролі;

3. стадії групових ігор, на якій діти навчаються розуміти, що від них очікують групи людей ${ }^{24}$.

Дж. Мід виділив три стадії соціалізації: імітація, рольові ігри, колективні ігри. На першій стадії діти імітують поведінку дорослих, не завжди розуміючи іiі. На другій стадії діти, виконуючи в іграх дорослі ролі, «приміряючи» їх до себе, учаться надавати своїм думкам і діям такого самого значення, що й дорослі. На третій, завершальній, стадії дитина до розуміння очікувань окремих людей додає групові очікування. Дотримання правил рольових і колективних ігор готує дітей до правил гри в суспільстві, закріплених у законах і нормах. Тим самим набувається почуття соціальної ідентичності ${ }^{25}$.

Соціальна сутність особистості розкрита в працях М. Вебера й Е. Дюркгейма, зокрема науковцями розроблені концепції освіти як соціального феномена. Для вивчення проблем соціалізації велике значення має обгрунтоване $\mathrm{M}$. Вебером розуміння соціальної поведінки, соціальної дії та взаємодії. М. Вебер, пояснюючи поведінку людини, коли суб'єктивно осмислені дії індивіда співвідносяться 3 поведінкою інших людей, уводить поняття «суспільно орієнтовані дії». Ці дії припускають суб'єктивну мотивацію індивіда або групи й осмислену орієнтованість на інших. У дослідженнях стосунків людини та суспільства Е. Дюркгейм неодноразово звертався до питань виховання молодшого покоління, під якими він фактично мав на увазі соціалізацію, практично не розводячи цей термін. Е. Дюркгейм розумів

23 Тард Г. Социальная логика / пер. с франц. М. Цейтлин. Санкт-Петербург : Социально-психологический центр, 1996. С. 66.

${ }^{24}$ Смелзер Н. Социология : учебное пособие / пер. с англ. Москва : Феникс, 1998. C. 534.

${ }^{25}$ Соціологія : навчальний посібник для студ. вищ. навч. закладів / за заг. ред. B.I. Докаша. 2-ге вид., доопр., доп. Чернівці : Чернівецький нац. ун-т, 2012. С. 87. 
під вихованням «постійне випробовування дитини тиском соціального середовища, що прагне сформувати його за своїм зразком і має своїми представниками й посередниками батьків і вчителів». Зміст позиції Е. Дюркгейма зводиться до визнання пріоритету суспільства у формуванні особистості, а сам процес соціалізації - до адаптації людини в суспільстві, яке формує її відповідно до своєї культури ${ }^{26}$.

Французький психолог Ж. Піаже наголошує на розвитку пізнавальних структур індивіда і їхній наступній перебудові залежно від досвіду й соціальної взаємодії. Учений зробив спробу визначити етапи пізнавальної соціалізації людини, уважаючи, що когнітивна соціалізація проходить декілька стадій, кожна 3 яких окреслюється новими навичками: сенсорно-моторна (від народження до 2 років), операційна (від 2 до 7), стадія конкретних операцій (з 7 до 11), стадія формальних операцій (з 12 до 15). Діти, на його думку, проходять ці стадії в певній послідовності, хоча швидкість і результативність цього процесу може бути різною залежно від потенційних здібностей, виховання, бажання та впливу оточення ${ }^{27}$.

На думку Л. Орбан-Лембрик основними механізми соціалізації можна виділити: а) цілеспрямоване формування особистості; б) стихійний вплив на особистість різних обставин життя. Соціалізація ж як одиничний процес, уважає вчений, пов'язана $з$ індивідуалізацією особистості, виробленням нею власного стилю спілкування, власної лінії поведінки, набуттям особистісного комунікативного досвіду, чинниками соціалізації $є$ : очікування, зміна поведінки і прагнення відповідати цим очікуванням. Оскільки під дією цих чинників індивід проявляє свою соціальну сутність, формує соціальні якості, набуває особистісного життєвого досвіду, комунікативних умінь та навичок, розвиває власне «Я» та набуває комунікативності. Отже, основними формами соціалізації можна вважати діяльність, самосвідомість і спілкування. Процес соціалізації Л. Орбан-Лембрик уважав двостороннім: 3 одного боку, передбачає засвоєння індивідом соціального досвіду шляхом входження в соціальне середовище, систему соціальних зв'язків, а з іншого - активне відтворення цих зв'язків через реалізацію власного комунікативного досвіду. Тобто людина не тільки адаптується до умов соціуму, його культури, норм, а й перетворює їх у власні цінності, орієнтації та установки, стаючи тим самим особистістю ${ }^{28}$. Розмаїття концепцій у визначенні сутності

${ }^{26}$ Дюркгейм Е. Метод соціології. Київ ; Харків, 1899. С. 12-13.

${ }^{27}$ Социализация. Знание. Понимание. Умение. Москва, 2004. № 1. С. 139-143.

28 Орбан-Лембрик Л.Е. Психологія професійної комунікації : навчальний посібник. Чернівці : Книги XXI, 2010. С. 66-67. 
соціалізації, що існує у вітчизняній науковій літературі, дає можливість здійснити їх класифікацію за різними ознаками.

Філософський підхід В. Москаленко до проблеми соціалізації особистості відзначається тим, що вона визначає поняття соціалізації особистості як процес взаємодії індивіда й суспільства на підставі предметно-перетворювальної діяльності індивіда, наслідком чого $\epsilon$ конкретно-історична форма його соціальності ${ }^{29}$.

Представник соціологічної думки Ян Щепанський визначає соціалізацію як цілісність усіх впливів соціального та культурного середовища, що спонтанно вчать індивіда адаптуватися до структури певних конкретних соціальних груп і звичаїв, зразків поведінки ${ }^{30}$.

Культурологічна концепція розглядає соціалізацію 3 позиції засвоєння індивідом культури суспільства, у якому формується особистість. При цьому культура $є$ передумовою, кінцевою метою й результатом соціалізації, своєрідним механізмом трансляції духовної культури від покоління до покоління. У змістовому плані соціалізація визначається як процес засвоєння знань і навичок, необхідних людині для того, щоб стати членом суспільства, адекватно діяти та взаємодіяти зі своїм соціокультурним оточенням, сформувати свій спосіб життя.

Реалізація культурологічного підходу забезпечує входження дитини у світ культури, що передбачає засвоєння нею духовно-культурних надбань людства, дає можливість використовувати особистісний потенціал, залучати дітей до власної життєтворчості, формувати почуття причетності дитини до певної культури. Зорієнтований на культурні зразки, педагогічний процес закладу дошкільної освіти, в основі якого - соціокультурний зміст, діалогічна взаємодія між однолітками та дорослими як партнерами, обмін цінностями, культурна ідентифікація, творча самореалізація кожної особистості, сприяє розумінню соціалізації як процесу прилучення дитини до культури суспільства ${ }^{31}$.

У соціальній психології соціалізація особистості практично ототожнюється із соціальною адаптацією в широкому іiі розумінні. Соціальна адаптація $є$ інтегративним показником стану людини, який віддзеркалює іiі можливості виконувати певні біосоціальні функції: адекватне сприйняття соціальної дійсності й власного організму;

${ }^{29}$ Москаленко В.В. Социализация личности (философский аспект). Киев : Вища школа, 1986. С. 189.

30 Авраменко О.О. Проблема соціалізації особистості в дослідженнях зарубіжних вчених. Педагогічна теорія і практика : збірник наукових праць. Київ : КиМУ, 2013. Вип. 4. С. 3-14.

31 Рогальська І.П. Теоретико-методичні засади соціалізації особистості у дошкільному дитинстві : автореф. дис. ... докт. пед. наук. Луганськ, 2009. С. 18-22. 
адекватну систему взаємин і стосунків 3 оточенням; спроможність до праці, навчання, дозвілля; здатність до самообслуговування i взаємообслуговування в сім’ї та колективі; адаптивність поведінки відповідно до рольових очікувань інших.

Соціальна адаптація (від лат. adapto - пристосування) розглядається соціологами як вид взаємодії особи із соціальним середовищем, у ході якого відбувається погодження вимог і сподівань обох взаємодіючих сторін. Це можна вважати пристосуванням індивіда до різних рольових функцій, соціальних норм, спільностей і до умов функціонування різноманітних сфер життєдіяльності суспільства. Інтеріоризація (від лат. interior - внутрішній) - процес формування внутрішньої структури людської психіки за допомогою засвоєння соціальних норм, цінностей, ідеалів; це процес переведення елементів зовнішнього середовища (суспільної культури) у внутрішнє «Я» ${ }^{32}$.

Дефініцію «соціальна адаптація» К. Крутій, О. Фунтікова розглядають як «соціальне пристосування, процес або результат процесу, який передбачає гармонійне, 3 погляду індивідуальних прагнень людини, задоволення ऑї потреб, створення умов для іiі здорового, щасливого життя в суспільстві» ${ }^{33}$. Соціальну адаптацію Р. Атаєва детермінує як «історично зумовлений, обмежений у часі й такий, що має активно перетворювальний характер, процес пристосування особистості до умов соціального середовища, що постійно змінюються, впливу цього середовища, а також результат цього процесу» ${ }^{34}$.

Соціальна адаптація - пристосування індивіда до умов соціального середовища, формування адекватної системи відносин із соціальними об'єктами, рольова пластичність поведінки, інтеграція особистості в соціальні групи, діяльність щодо освоєння стабільних соціальних умов, прийняття норм і цінностей нового соціального середовища, форм соціальної взаємодії.

Розрізняють два види соціальної адаптації: активну й пасивну. У процесі активної адаптації індивід прагне енергійно взаємодіяти із середовищем, впливати на його розвиток і зміни, долати труднощі й перепони, удосконалювати суспільні процеси. За пасивної адаптації індивід не прагне до змін навколишньої дійсності, пасивно приймає

32 Орбан-Лембрик Л.Е. Психологія професійної комунікації : навчальний посібник. Чернівці : Книги XXI, 2010. С. 65-66.

33 Дошкільна освіта : словник-довідник : понад 1000 термінів, понять та назв / упор. К.Л. Крутій, О.О. Фунтікова. Запоріжжя : ТОВ «ЛІПС» ЛТД, 2010. С. 15.

Атаева Р.Д. Педагогические условия социальной адаптации подростков в инновационной гимназии с поликультурной средой : дис. ... канд. пед. наук. Ставрополь, 2004. С. 41. 
чинні норми, оцінки, способи діяльності, слабко мобілізує біологічні та психологічні ресурси для пристосування в соціальному середовищі ${ }^{35}$. Важливим компонентом соціальної адаптації $є$ узгодженість оцінок, особистих можливостей і домагань індивіда із цілями, цінностями соціального середовища.

У найширшому розумінні під соціальним середовищем розуміють усю соціальну дійсність (державу, суспільство); у більш вузькому середовище, яке безпосередньо оточує дитину й тим самим впливає на іiі розвиток, формування характеру, інтересів, нахилів, ціннісних оріснтацій тощо. Виходячи 3 такого розуміння природи людини, «ії поведінка й діяльність, формування всіх іiі психологічних функцій нерозривно пов'язані з навколишнім середовищем і зумовлюється ним» ${ }^{36}$.

Соціальне середовище - це складне структурне утворення, яке характеризується взаємопов'язаними зв'язками та відносинами між його складовими. За визначенням Р. Павелкова, соціальне середовище становить єдність таких складників: макросередовища (суспільства як певної соціально-політичної, соціально-економічної та ідеологічної системи), мезосередовища (національно-культурних, соціальних особливостей регіону), мікросередовища (безпосереднього середовища життєдіяльності дитини: сім'ї, сусідів, групи однолітків, культурних, навчально-виховних закладів). У різні періоди дитинства ці складники соціального середовища значною мірою впливають на соціалізацію дітей дошкільного віку ${ }^{37}$.

Аналіз теоретичних джерел із дослідженої проблеми дав змогу 3'ясувати, що методологічною основою для розуміння процесу соціального становлення дитини у вітчизняній психології XX століття стали положення теорії психічного розвитку, висунуті й обгрунтовані в працях російських учених: Л. Божович, Л. Виготського Д. Ельконіна, О. Леонтьєва, М. Лісіноі ${ }^{38 ;} 39 ; 40 ; 41 ; 42$ та ін.

35 Безпалько О.В. Соціальна педагогіка: схеми, таблиці, коментарі: навчальний посібник для студ. вищ. навч. закл. Київ : Центр учбової літератури, 2009. С. 27.

36 Лукашевич М.П. Соціалізація. Виховні механізми і технології : навчальнометодичний посібник. Київ : ІЗМН, 1998. С. 55.

${ }^{37}$ Павелків Р.В., Цигипало О.П. Дитяча психологія : навчальний посібник. Київ : Академвидав, 2008. С. 42.

38 Божович Л.И. Личность и ее формирование в детском возрасте (Психологическое исследование). Москва : Просвещение, 1968. С. 44.

39 Выготский Л.С. Детская психология : собр. соч. : в 6 т. / под ред. Д.Б. Эльконина. Москва : Педагогика, 1984. Т 4. С. 255.

40 Эльконин Д.Б. Детская психология. Москва : Политиздат, 1960. С. 63.

41 Леонтьев А.Н. Деятельность. Сознание. Личность. 2-е изд. Москва : Политиздат, 1977. С. 255. 
Вони формулювали теоретичні положення виходячи 3 того, що для розуміння розвитку неможливо розглядати дитину як відокремленого індивіда, необхідно враховувати соціальну ситуацію розвитку, яка $є$ специфічною для кожного віку й закономірно визначає спосіб життя дитини, провідну діяльність і психологічні новоутворення.

Так, на думку Л. Виготського, соціалізація - це процес засвоєння індивідом суспільного досвіду, культурних надбань суспільства (культурно-історична концепція розвитку людини). Науковець указує на те, що соціалізація близька до «окультурення», тобто засвоєння соціального досвіду дитини проходить під час взаємодії з людьми носіями цього досвіду. Учений наголошував на тому, що досвід, якого набуває дитина, переробляється й повертається в культуру через ії певні індивідуальні досягнення. Учений заперечував розуміння стосунків соціального й індивідуального як ворожих, коли соціальне витісняє природне, зумовлюючи «окультурення» індивіда ${ }^{43}$. Основою розвитку особистості, за твердженням О. Асмолова, $є$ процес соціалізації та виховання в конкретній соціально-історичній системі координат епохи. У процесі діяльності в структурі відносин виникають системні якості людини, що характеризуються особистісним значенням, соціальні норми, цінності, ідеали, які стають «безособистісними передумовами» іiі розвитку. Дитина індивідуалізується та намагається зробити самостійний вибір того способу життя, який визначає іiі подальший розвиток у структурі суспільних відносин. Тобто відбувається засвоєння культурних надбань людства заради свідомого оволодіння способом власного життя ${ }^{44}$.

Відомий український психолог Г. Костюк визначав: «Розвиток безперервний процес, що виявляється в кількісних змінах людської істоти, тобто збільшення одних і зменшення інших ознак (фізичних, фізіологічних, психічних тощо). Однак він не зводиться до кількісних змін, до зростання того, що вже є, а включає «перерви безперервності», тобто якісні зміни. Кількісні зміни зумовлюють виникнення нових якостей, тобто ознак, властивостей, які утворюються в ході самого розвитку і зникнення старих» ${ }^{45}$.

42 Лисина М.И. Проблемы онтогенеза общения / Науч.-исслед. ин-т общей и педагогической психологии Акад. пед. наук СССР. Москва : Педагогика, 1986. C. $65-66$.

43 Выготский Л.С. Детская психология : собр. соч. : в 6 т. / под ред. Д.Б. Эльконина. Москва : Педагогика, 1984. Т 4. С. 123.

44 Асмолов А.Г. Психология личности: Принципы общепсихологического анализа : учебник. М. : Издательство МГУ, 1990. С. 161-162.

${ }^{45}$ Костюк Г.С. Избранные психологические труды. Москва : Педагогика, 1988. C. 34 . 
На думку А. Петровського, розвиток особистості - це закономірна зміна фаз адаптації, індивідуалізації та інтеграції. Процес соціального розвитку особистості, за твердженням ученого, є об'єднанням двох моделей: перша - описує фази розвитку особистості під час входження до нової референтної групи, друга - періоди вікового розвитку особистості ${ }^{46}$ А. Петровський виділив три фази соціального становлення людини - адаптацію, індивідуалізацію.

«Соціальний розвиток - це засвоєння дитиною досягнень суспільноісторичного досвіду спілкування, взаємодії, співробітництва 3 дорослими й однолітками» ${ }^{47}$. У результаті соціального розвитку засвоюється певний обсяг соціальної інформації, система ціннісних орієнтацій, формується досвід соціальної діяльності, здатність до спілкування з оточуючими ${ }^{48}$.

Зміст соціального розвитку особистості визначається, з одного боку, сукупністю соціальних впливів світового рівня культури, загальнолюдських цінностей, а з іншого - ставленням до цього самого індивіда, актуалізацією власного «Я», розкриттям творчого потенціалу особистості. Головним критерієм соціального розвитку в цьому випадку є не стільки ступінь засвоєння соціальних норм і правил поведінки, адаптованості до навколишнього світу на рівні конформізму, скільки ступінь самостійності, ініціативності, творчості особистості.

Соціальний розвиток особистості $\epsilon$ взаємопов'язаним процесом соціалізації-індивідуалізації дитини дошкільного віку, який, з одного боку, містить засвоєння соціокультурного досвіду у вигляді правил, норм, способів поведінки, еталонів дії та взаємодії людей у соціумі, а 3 іншого - розвиває сутнісне «Я» дитини, ¥іі індивідуальність i неповторність, надає певної автономності й незалежності від соціуму, здатності гармонійно та ефективно адаптуватися до нових умов постійно змінюваного соціального середовища ${ }^{49}$.

Соціальний розвиток дитини проходить двома пов'язаними лініями - соціалізації (оволодіння дитиною суспільним досвідом) та індивідуалізації (набуття нею самостійності, відносної автономності).

46 Петровский А.В. Проблема развития личности с позиции социальной психологи. Вопросы психологии. 1984. № 4. С. 15-30.

47 Социальное развитие. Краткий словарь по социологии / под ред. Д.М. Гришиани, Н.И Лапина; сост. З.М. Коржева, Н.Ф. Наумова. Москва : Политиздат, 1988. С. 272-273.

48 Мухина В.С. К проблеме социального развития ребёнка. Психологический журнал. 1980. Т. 1. № 5. С. 58-60.

49 Рогальська І.П. Теоретико-методичні засади соціалізації особистості у дошкільному дитинстві : автореф. дис. ... докт. пед. наук. Луганськ, 2009. С. 43. 
Вивчення соціального розвитку дитини 3 погляду його змістової сутності (соціалізації-індивідуалізації) дає змогу визначити психологічні механізми становлення цього процесу в онтогенезі. Соціальний досвід, до якого прилучається дитина 3 перших років свого життя, акумулюється й виявляється в соціальній культурі. Засвоєння культурних цінностей, їх перетворення, що сприяють суспільному процесові, $є$ однією з фундаментальних завдань соціалізації. Проте соціальний розвиток можливий тільки тоді, коли дитина не тільки засвоює соціальний досвід попередніх поколінь, а й доповнює, поглиблює, формує сучасними надбаннями.

Соціальний досвід, до якого прилучається дитина 3 перших років свого життя, акумулюється й виявляється в соціальній культурі. Засвоєння культурних цінностей, їх перетворення, що сприяє суспільному процесові, $\epsilon$ одним із фундаментальних завдань соціалізації

Основним чинником соціального розвитку є знання норм і правил спілкування з іншими людьми, тобто здатність осмислювати процес спілкування та прогнозувати різноманітні ситуації спілкування. Будьяка взаємодія дитини 3 довкіллям відбувається в процесі спілкування, форми якого в дитини міняються залежно від віку. До семи років у дитини змінюються чотири форми спілкування 3 дорослими: ситуативно-особистісна, ситуативно-ділова, ситуативно-пізнавальна й ситуативно-особистісна. Досвід свого спілкування 3 дорослими дитина переносить у ситуації спілкування з іншими дітьми ${ }^{51}$.

Проте особистістю дитина стає в результаті самоуправління, коли вона починає певною мірою впливати на своє життя. У дошкільному дитинстві вона здійснює це переважно з допомогою дорослих, а в наступні періоди - усе більш самостійно.

Соціальний розвиток можливий тільки тоді, коли дитина не тільки засвоює соціальний досвід попередніх поколінь, а й доповнює, поглиблює, формує його сучасними надбаннями.

На думку Д. Фельдштейна, розвиток дитини в онтогенезі відбувається за цілеспрямованого включення ії в систему діяльності. Саме в конкретних типах діяльності дітей і виявляються дві її сторони: наочно-практична й діяльність, спрямована на розвиток взаємостосунків. При цьому актуалізація певної сторони діяльності здійснюється в тих ії типах, які найбільше забезпечують на відповідних

${ }^{50}$ Авраменко О.О. Педагогічна спадщина В.О. Сухомлинського як джерело ідей щодо різновікового об'єднання дітей. Наукові записки. Серія «Педагогічні науки». Кіровоград : РВВ КДПУ ім. В. Винниченка, 2008. Вип. 78 (2). С. 120-125.

51 Вопросы психологии ребенка дошкольного возраста / под ред. А.Н. Леонтьева, А.В. Запорожца. Москва-Ленинград : Изд-во АПН РСФСР, 1948. C. 51-58. 
етапах онтогенезу процес соціалізації й індивідуалізації як провідні моменти розвитку. Уже через соціальну сутність діяльності в процесі її розвитку відбувається формування соціальних відносин людини, іiі суб'єктивного світу. Найважливішим компонентом соціальних утворень дитини виступає позиція «я», поступальний розвиток якої йде від усвідомлення дитиною своїх соціальних можливостей до чіткого прояву, зміцнення, якісної зміни соціальної позиції в результаті власної творчої активності ${ }^{52}$.

Два типи позицій дитини щодо суспільства виділяє Д. Фельдштейн, які реально існують («я в суспільстві» та «я і суспільство»). Саме позиція «я» у ставленні до суспільства повно відображає результати соціального розвитку в онтогенезі. Обидва типи цієї позиції чітко пов'язані з певними періодами, етапами онтогенезу. Позиція «я в суспільстві» пов'язана 3 освоєнням наочно-практичної сторони діяльності - знарядь, знаків, соціально заданих дій, способів поводження з предметами. Загалом це процес соціалізації дитини. Позиція «я і суспільство» пов'язана 3 діяльністю, спрямованою на засвоєння норм людських взаємостосунків. Цей процес забезпечує індивідуалізацію особистості. Позиція «я в суспільстві» формується в періоди раннього дитинства (1-3 роки), молодшого шкільного (6-9 років) і старшого шкільного (15-17 років) віків. Позиція «я і суспільство» розгортається найбільш активно в дошкільному (3-6 років) і підлітковому (10-15 років) віці ${ }^{53}$.

Ступенем соціального розвитку дитини, рівнем іï соціальної компетентності визначається успішність соціалізації дошкільника, що дає дитині змогу посісти гідне місце в системі взаємин із дорослими й однолітками в мікросередовищі: родині та групі дошкільного навчального закладу. Основним чинником соціального розвитку $€$ знання норм і правил спілкування з іншими людьми, тобто здатність осмислювати процес спілкування та прогнозувати різноманітні ситуації спілкування.

Результати дослідження І. Рогальської підтверджують необхідність проектування соціально-педагогічного супроводу соціалізації особистості в дошкільному дитинстві. Соціально-педагогічний супровід соціалізації передбачає рух разом із дитиною, поруч із нею, тому акцент ставиться на створенні соціального простору дитинства, що зумовлює процес соціалізації особистості дитини. Виділені такі складники соціального простору: суспільне довкілля, до якого

52 Фельдштейн Д.И. Закономерности развития деятельности как основа развития личности : хрестоматия по возрастной психологи : учебное пособие для студентов. Москва, 2006. С. 65.

${ }^{53}$ Фельдштейн Д.И. Закономерности развития деятельности как основа развития личности : хрестоматия по возрастной психологи : учебное пособие для студентов. Москва, 2006. С. 178-194. 
належить світ дорослих і світ дітей; культурологічна домінанта змісту дошкільної освіти; цілісна картина світу, що відображається в дитячій субкультурі. За наявності соціального простору дитина вибудовує свої стосунки зі світом людей і світом власного «Я» й опановує продуктивні способи соціальної взаємодії, що дає їй можливість засвоювати позиції об'єкта й суб'єкта соціалізації та виявляти себе суб'єктом власної життєтворчості ${ }^{54}$.

Педагогічні концепції, як правило, трактують соціалізацію в тісній взаємодії з процесом виховання та визначають соціально-педагогічні механізми соціалізації, що вказують на зміст і методи виховання. Соціалізація забезпечує входження людини в соціальні спільноти й колективи, комфортне співіснування в них, усуспільнення іiі діяльності, способу життя й думок, що забезпечує формування особистості як представника певних соціальних спільнот і груп, соціальних прошарків. Дослідники проблеми соціалізації дитини, говорячи про виховання особистості, мають на увазі насамперед формування готовності до реалізації індивідом сукупності соціальних ролей. При цьому сам процес освоєння цих ролей, передбачає участь кожного вихованця в діяльності й навчанні. Соціальна роль розкриває механізм засвоєння дитиною соціального досвіду.

Отже, аналіз тлумачень сутності соціалізації, що існують у концепціях і теоріях соціалізації (соціологічна, культурологічна, соціально-психологічна, педагогічна концепції), свідчить, що сутнісними ознаками соціалізації $\epsilon$ процес впливу соціального середовища на індивіда, передавання культурного досвіду, адаптація до соціальних умов, цілеспрямоване формування колективістських якостей. Наведені розбіжності певною мірою зумовлені предметною специфікою кожної з галузей наукового знання.

Одним зі складників методології дослідження $є$ педагогічна теорія соціалізації, що дала змогу осмислити освітній процес у різновіковій групі дошкільного навчального закладу в контексті взаємодії факторів, що впливають на особистість, яка соціалізується.

Характеристика процесу соціалізації як системи, розроблення основ iii теорії, дослідження соціально-педагогічної природи системи соціалізації знайшли відображення в працях вітчизняних учених: І. Звєрєвої, Л. Коваль, О. Караман, М. Лукашевича, В. Слюсаревського, Ю. Сичова, В. Ільїна, Т. Білонова, Л. Міщик, Н. Щуркової та ін.

Розроблено вітчизняні й зарубіжні концепції соціалізації особистості (І. Звєрєва, А. Капська, А. Мудрик, І. Рогальська, С. Харченко та ін.); розкрито соціально-педагогічні аспекти проблеми (О. Бодальов,

54 Рогальська І.П. Теоретико-методичні засади соціалізації особистості у дошкільному дитинстві : автореф. дис. ... докт. пед. наук. Луганськ, 2009. С. 28. 
В. Караковський, С. Литвиненко, А. Мудрик, Л. Новикова, Я. Щепанський, I. Кон та ін.); визначено соціальну компетентність особистості на ранніх етапах соціалізації (Ю. Богинська, О. Караман, О. Кононко, С. Курінна, I. Печенко, Р. Пріма та ін.).

Соціальна педагогіка в останнє десятиліття намагається осмислити процес соціалізації як явище педагогічне. Теоретичний аналіз, проведений Н. Головановою, дав змогу виділити такі основні підходи до педагогічної характеристики поняття «соціалізації»:

- соціологічний (Л. Левшин, Х. Лійметс, Т. Мальковська, В. Момов та ін.), коли соціалізація розглядається як трансляція культури від покоління до покоління, як загальний механізм соціального успадкування, що охоплює i стихійні, й організовані впливи середовища;

- факторно-інституціональний (В. Гінецинський, I. Кон, А. Мудрик та ін.), де соціалізація розглядається як сукупність дії факторів, інститутів та агентів соціалізації;

- інтеракціональний підхід (Т. Коннікова, А. Куракін, А. Мудрик, Л. Новікова та ін.), що розглядає соціалізацію в контексті спілкування, міжособистісної взаємодії;

- інтеріоризаціональний підхід (Б. Бітінас, Л. Буєва, І. Кон, В. Крутецький та ін.), у межах якого соціалізація розуміється як процес освоєння особистістю норм, цінностей, установок, вироблених суспільством, що приводить до становлення системи внутрішніх регуляторів;

- інтраіндивідуальний підхід, де соціалізація не вичерпується пристосуванням особистості до соціального середовища, а є творчою самореалізацією особистості, удосконаленням себе (I. Кон, А. Кочетов, Т. Мальковська, Л. Рувінський, В. Шепель та ін. $)^{55}$.

У радянській науці перші дослідження проблем соціалізації 3'явилися наприкінці 60-х років XX століття. Увага акцентувалася передусім на тому, що це процес засвоєння соціальних норм і цінностей. Б. Паригін, який співвідносить соціалізацію з усім ходом історичного розвитку людства, указував, що не лише виникнення людини, виокремлення іiі зі світу тварин, а й загальний хід розвитку людства був процесом соціалізації. На його думку, соціалізація становить «багатогранний процес, що включає в себе як біологічні передумови, так і безпосередньо саме входження індивіда в соціальне середовище, і передбачає соціальне пізнання, соціальне спілкування, оволодіння навичками практичної діяльності, включаючи як предметний світ речей, так і усю сукупність соціальних функцій, ролей,

55 Голованова Н.Ф. Педагогические основы социализации младшего школьника : дисс. ... докт. пед. наук. Санкт-Петербург, 1997. С. 193. 
норм, обов'язків тощо, активну перебудову навколишнього (як предметного, так і соціального) світу» ${ }^{56}$.

Таке бачення збігається 3 визначенням I. Кона, який розглядає соціалізацію як процес засвоєння індивідом соціального досвіду, у ході якого створюється конкретна особистість, як процес засвоєння певної системи соціальних ролей і культури ${ }^{57}$.

Учений звертає увагу на те, що саме «в процесі соціалізації індивіди не просто адаптуються до середовища й засвоюють наявні в ньому соціальні ролі та ідентичності, а й навчаються «встановлювати, підтримувати і змінювати такі ідентичності», перетворюючи тим самим самих себе і навколишній світ» ${ }^{58}$.

$\mathrm{У}$ 70-ті роки $\mathrm{XX}$ століття над різними аспектами процесу соціалізації особистості, у тому числі й термінологічним осмисленням, працювали С. Кузьмін, Ю. Левада, В. Марков, А. Мудрик, В. Сухомлинський та ін.

Так, Є. Кузьмін наполягав на пріоритетності дії таких механізмів соціалізації, як наслідування, навіювання, конформізм, свідоме наслідування зразкам, вплив масових засобів комунікації та культури ${ }^{59}$.

Чимало дослідників акцентують увагу на моменті засвоєння індивідом соціального досвіду, соціальних цінностей, норм, знань. Так, Ю. Левада доходить висновку, що поняття соціалізації є «засвоєнням людиною норм культури», і проходить вона в малій групі найближчого оточення ${ }^{60}$.

Російський дослідник А. Мудрик тлумачить аналізоване поняття як «процес розвитку людини у взаємодії з навколишнім світом» і подає його як сукупність чотирьох складників:

- стихійна соціалізація в процесі стихійної взаємодії людини із суспільством i стихійного впливу на неї різних, зазвичай різноспрямованих обставин життя;

- відносно керована соціалізація у процесі та результаті впливу з боку держави на обставини життя тих або інших категорій громадян;

- відносно соціально контрольована соціалізація в процесі планомірного створення суспільством і державою умов для виховання людини;

56 Парыгин Б.Д. Основы социально-психологической теории. Москва : Мысль, 1971. С. 165.

57 Кон И.С. Психология ранней юности : книга для учителя. Москва : Просвещение, 1989. С. 134.

58 Кон И.С. Ребенок и общество : учебное пособие для студ. высш. учеб. заведений. Москва : Издательский центр «Академия», 2003. С. 152.

${ }^{59}$ Кузьмин Е.С. Основы социальной психологии. Ленинград : ЛГУ, 1967. С. 170.

${ }^{60}$ Левада Ю.А. Собрание сочинений. Москва : Наука, 1970. С. 324. 
- більш або менш свідома самозміна людини ${ }^{61}$.

Науковець підкреслює, що, досліджуючи проблему соціалізації особистості в дошкільному дитинстві, важливо орієнтуватися на найширше поняття серед процесів, що характеризують становлення особистості, бо воно позначає «розвиток, зумовлений конкретними соціальними умовами» ${ }^{62}$.

Сім'я як персональне середовище розвитку - один із найважливіших інститутів соціалізації особистості, адже вона зумовлює спосіб життя дитини, iіi соціальне існування, впливає на формування нових соціальних якостей, умінь і навичок ${ }^{63}$.

Однак соціальне середовище, зокрема сім'я, може як сприяти процесам розвитку дитини, так і стримувати їх. Натепер реальне становище дітей дає змогу фіксувати значні обмеження, недостатнє забезпечення як матеріальних, так $\mathrm{i}$ духовних ресурсів, які $\epsilon$ необхідними для повноцінної соціалізації в сучасних складних умовах $^{64}$.

«Соціальні сироти», «безпритульні», «безоглядні», «жертви насилля» - це далеко не повний перелік дітей, що опинилися в складній небезпечній ситуації, яку вони не спроможні розв'язати самостійно. При цьому найбільш вражаючим $\epsilon$ те, що серед цих дітей $15 \%$ (за даними соціальних органів) - діти дошкільного віку. Як засвідчують соціальні органи, у країні нараховується 82 тисячі неблагополучних сімей, у яких проявляється безвідповідальне ставлення батьків до виконання своїх виховних функцій, жорстоке поводження 3 дітьми, наявне фізичне та психічне насильство, агресія в сім'ї. Крім того, сьогодні викликає тривогу зменшення тривалості й значне збіднення змісту спілкування членів родини, зникнення спільних форм діяльності батьків і дітей ${ }^{65}$.

${ }^{61}$ Мудрик А. Социализация человека как проблема. Социальная педагогика. 2005. № 4. C. 47-57.

${ }_{62}$ Мудрик А. В. Социальная педагогика : учебное пособие. Москва : Академия, 1999. С. 155.

63 Божович Л.И. Личность и ее формирование в детском возрасте (Психологическое исследование). Москва : Просвещение, 1968. С. 39-40.

64 Карнаух Л. Особливості соціалізації дітей дошкільного віку в умовах сучасного соціального середовища. Психолого-педагогічні проблеми сільської школи. 2012. № 40. С. 110-114.

65 Печенко I.П. Дитина в сучасному соціально-педагогічному просторі: проблема захисту прав. Збірник наукових праць Полтавського державного педагогічного університету ім. В.Г. Короленка. Серія «Педагогічні науки». Полтава, 2005. Вип. 6 (45). С. 45-53. 
Неблагополучна сім'я - це сім'я, яка через об'єктивні або суб'єктивні причини втратила свої виховні можливості, унаслідок чого в ній виникають несприятливі умови для виховання дитини ${ }^{66}$.

Негативні впливи сімейного оточення істотно спотворюють поведінку дитини, зумовлюють ранню втрату ії потреби у спілкуванні $з$ батьками, формуючи низку негативних поведінкових стереотипів та особистісних якостей (егоїзм, замкненість, конфліктність, упертість, неадекватну самооцінку (завищену чи занижену), озлобленість, невпевненість у власних силах, недисциплінованість тощо). У неблагополучній сім'ї спостерігається відкрите або приховане емоційне напруження дитини. Часті покарання, окрики, невдоволення 3 боку батьків примушують дитину думати, що ії не люблять, що вона нікому не потрібна. Це створює відповідний негативний емоційний дискомфорт у душі дитини.

На думку Л. Божович, посилюють фактор сімейного неблагополуччя недоліки виховання в родині, найбільш типовими з яких є такі:

1) несприйняття дитини, відверте або приховане емоційне відторгнення іiї батьками;

2) непослідовність виховання, що характеризується неузгодженістю педагогічних дій батьків та інших дорослих, що, у свою чергу, дезорієнтує дитину;

3) нерозуміння закономірностей і своєрідності розвитку дитини, невідповідність вимог та очікувань батьків можливостям і потребам дитини;

4) негнучкість виховних позицій батьків у взаєминах із дитиною, що виявляється в недостатньому врахуванні ситуації, у нав'язуванні дитині власної думки, у різкій зміні ставлення до дитини в різні періоди iї життя;

5) афективність - надмірне роздратування, невдоволення чи, навпаки, турботливість, тривога стосовно дитини, що створює в сім’ї ефект хаотичності, загального сум'яття;

6) авторитарність виховання - намагання підкорити дитину своїй волі, категоричність суджень, нав'язування своєї думки й готових рішень, використання примушування й репресивних заходів, зокрема фізичних покарань, постійний контроль за діями дитини ${ }^{67}$.

Як провідний мікрофактор соціалізації особистості Н. Пихтіна розглядала сім'ю, оскільки вона є персональним середовищем для життя й розвитку. 3'ясовано особливості несприятливої соціалізації

\footnotetext{
${ }^{66}$ Котова И.Б., Шиянов Е.Н. Социализация и воспитание. Ростов-на-Дону, 1997. C. 201.

Божович Л.И. Личность и ее формирование в детском возрасте (Психологическое исследование). Москва : Просвещение, 1968. С. 64.
} 
дошкільників у неблагополучних сім'ях, а саме: недостатність позитивного емоційного контакту між членами родини, неправильність виховних позицій батьків, ускладнення їхніх подружніх стосунків, аморальний спосіб життя батьків і їхня асоціальна поведінки. Вивчено їх негативний вплив на формування деструктивних рис характеру дітей, негативних стереотипів їхньої поведінки, виникнення негативних поведінкових проявів ${ }^{68}$.

Торкаючись проблеми соціального становлення особистості, В. Сухомлинський влучно зауважив, що «у людині іï людські риси формуються тільки тому, що з першого подиху свого життя вона істота суспільна. Суспільна сутність людини виявляється в ії стосунках, взаєминах з іншими людьми. Пізнаючи світ і себе як частину світу, вступаючи в стосунки 3 людьми, які задовольняють ii матеріальні й духовні потреби, дитина залучається до суспільства, стає його членом». За словами В. Сухомлинського, найтонші, найчутливіші корінці правильної соціалізації лежать у почуттях і переживаннях, «вони - ніби малесенький магніт, закладений у дитячій істоті, який притягує іiі до інших людей, робить іiі чутливішою, сприйнятливішою до слів, навчань, ідей, настанов» ${ }^{69}$.

\section{2. Теоретико-методологічні засади визначення сутності й змісту соціалізації особистості в сучасних науково-педагогічних дослідженнях}

У 80-90-ті роки минулого століття інтерес до соціалізації як до педагогічного феномена зростає. Саме в цей період питання структури, функцій, механізмів соціалізації, iї особливостей у сучасних умовах перебувають у центрі досліджень представників практично всіх суспільствознавчих дисциплін.

Можемо погодитися 3 поглядами Г. Андрєєвої, що соціалізація двобічний процес, який містить, з одного боку, засвоєння індивідом соціального досвіду шляхом входження в соціальне середовище, систему соціальних зв'язків; 3 іншого боку, процес активного відтворення індивідом систем соціальних зв'язків за рахунок його активної діяльності, активного включення в соціальне середовище $\mathrm{e}^{70}$.

Соціалізацію як процес формування особистості в певних соціальних умовах, засвоєння індивідом соціального досвіду, перетворення соціального досвіду у власні цінності й орієнтації,

${ }^{68}$ Пихтіна Н.П. Вплив стихійної соціалізації дітей дошкільного віку в умовах неблагополучної сім’ї на виникнення негативних проявів у їхній поведінці. Вісник Глухівського національного педагогічного університету імені Олександра Довженка. Серія «Педагогічні науки». 2018. Вип. 3. С. 104-112.

${ }^{69}$ Сухомлинський В.О. Вибрані твори : у 5 т. Київ : Рад. школа, 1976. Т. 2. С. 451.

${ }^{70}$ Андреева Г.М. Социальная психология. Москва : Аспект-Пресс, 1996. С. 176. 
залучення до своєї системи поведінки тих норм i шаблонів, які прийняті в суспільстві, визначає I. Татьянчикова. Крім того, соціалізацію трактують як безперервний процес, упродовж якого особистість набуває свого розвитку за умови проходження нею основних стадій. Стадії соціалізації умовно відповідають віковим етапам розвитку людини в онтогенезі та їі особистісного зростання (Столяренко, 2001; Татьянчикова, 2017) і передбачають адаптацію, індивідуалізацію, інтеграцію та трудову стадію (що конкретизоване до умов спеціальної школи як стадія ранньої трудової підготовки). На стадії адаптації відбувається пристосування до нових умов існування людини як організму як носія психічного й соціального; здійснюється активне, але некритичне, засвоєння дитиною соціального досвіду у вигляді знань і способів активності. Стадія індивідуалізації характеризується певним відособленням індивіда, основа якого полягає у виникненні потреби персоналізації; засвоєння досвіду відбувається критично; активно формується самосвідомість, що призводить до спроб виокремлення в дитячому середовищі. Стадії інтеграції притаманним є виникнення потреби та інтенції «входження» в суспільство в сукупності власних особливостей і можливостей 3 метою пошуку належного місця. На стадії ранньої трудової підготовки в умовах школи відбувається входження дитини в професійне середовище, формування в неї професійно важливих якостей, удосконалення трудових навичок 3 урахуванням виявлених психофізичних можливостей ${ }^{71}$.

На ці ж два взаємозумовлені процеси, що становлять сутність соціалізації, указує Б. Ломов, виділяючи момент входження індивіда в соціальне оточення, соціальне середовище, включення індивіда в систему суспільних відносин ${ }^{72}$.

Соціалізацію з позиції подвійного завдання розглядає М. Рожков: соціальної адаптації й соціальної автономізації, де соціальна адаптація покликана забезпечити активне пристосування особистості до соціального середовища, а соціальна автономізація - стійкість щодо неї, реалізацію власної «Я-концепції» ${ }^{73}$.

У працях В. Мухіної аналізується процес соціалізації як розвиток особистості через діалектичну єдність внутрішніх умов, передумов і внутрішньої позиції особистості, яка виникла в онтогенезі. Заслуговує на увагу обгрунтована думка дослідниці, що соціальний простір

71 Татьянчикова I., Омельченко М., Татьянчиков А. Психолого-педагогічне забезпечення соціалізації учнів 3 інтелектуальними порушеннями. Наука i ocвima. 2018. № 5. C. 109-117.

72 Ломов Б.Ф. Методологические и теоретические проблемы в психологии. Москва : Наука, 1984. С. 46.

73 Рожков М. Й. Концепция социализации ребенка в работе детских организаций. Москва : Академия, 1991. С. 87. 
освоюється дитиною поступово, через іï прагнення реалізувати своє домагання на визнання. А отже, в основі цього аспекту закладене бажання дитини отримати «соціальне схвалення» й бути оціненою як «хороша» дитина. Тобто особистість так виробляє ціннісне ставлення до того, що «потрібно», засвоює моральні норми ${ }^{74}$.

Соціалізація особистості у взаємодії 3 різними факторами (мегафактори, макро-, мезо- та мікрофактори) й агентами (людьми, 3 якими безпосередньо взаємодіє дитина) відбувається за допомогою низки «механізмів». За позицією В. Мухіної, механізмом соціалізації виявляється ідентифікація та уособлення особистості й закономірна зміна фаз адаптації, індивідуалізації та інтеграції в процесі розвитку особистості.

Соціалізація, на думку А. Капської, - це процес послідовного входження індивіда в соціальне середовище, що супроводжується засвоєнням і відтворенням культури суспільства внаслідок взаємодії людини зі стихійними та цілеспрямовано створюваними умовами життя на всіх їі вікових етапах ${ }^{75}$.

До соціально-педагогічних механізмів соціалізації вчена зараховує традиційний механізм соціалізації, пов'язаний із засвоєнням дитиною норм, еталонів поведінки, поглядів, стереотипів, характерних для їі сім'ї та найближчого оточення, які засвоюються на неусвідомленому чи підсвідомому рівні за допомогою некритичного сприйняття панівних домінант.

Інституціональний механізм соціалізації функціонує в процесі взаємодії людини з інститутами суспільства та різними організаціями, які спеціально створені для її соціалізації й опосередковано реалізують виховні функції, паралельно зі своїми іншими функціями. Не менш значущим для дошкільного віку $є$ міжособистісний механізм соціалізації як взаємодія людини із суб'єктивно значущими для неї іншими людьми. В основі цього механізму соціалізації лежить психологічний акт міжособистісного перенесення певного соціального досвіду від однолітків, батьків, знайомих, які $\epsilon$ носіями певних субкультур, незалежно від того, чи то позитивний, чи то негативний досвід. Унікальне поєднання в кожному окремому випадку різноманітних механізмів соціалізації стосовно процесу становлення кожної окремої дитини зумовлює той чи інший вектор засвоєння й упровадження власної соціальної позиції ${ }^{76}$.

74 Мухина В.С. Возрастная психология : учебник для студ. высш. учеб. заведений. Москва : Академия, 1997. С. 71.

75 Соціальна педагогіка : підручник / за ред. А. Капської. Київ : Центр навчальної літератури, 2003. С. 201-203.

76 Соціальна педагогіка : підручник / за ред. А. Капської. Київ : Центр навчальної літератури, 2003. С. 157. 
Становлення особистості як суспільної істоти, під час якого складаються різноманітні зв'язки особистості із суспільством, засвоюються орієнтації, цінності, норми, відбувається розвиток особистісних властивостей, формується активність і цілісність особистості, набувається соціальний досвід, що нагромаджений людством за весь період розвитку, М. Лукашевич розглядає як процес iii соціалізації ${ }^{77}$.

У 90-х роках ХХ століття в Україні відбувається становлення нової парадигми виховання, засадами якої $\epsilon$ гуманізація та демократизація педагогічного процесу, формування загальнолюдських і національних цінностей та ідеалів. На цьому етапі розвитку педагогічної науки увага науковців особливо акцентується на формуванні національної ідентичності особистості, наслідком якої стає ii національна самоідентифікація. Моделюючи вимоги до системи національного виховання, науковці Л. Артемова, А. Богуш, В. Кузь, Г. Лозко, Р. Пріма, Н. Рогальська, Ю. Руденко, М. Стельмахович та ін. визначають структурні компоненти цієї системи й засоби ії реалізації, завдяки яким дитина має рівні права та можливості з дорослими на соціальний, психічний, культурний розвиток як особистість та індивід.

Розробленню соціально-педагогічних характеристик процесу соціального становлення особистості присвячено праці Л. Байбородової, О. Безпалько, А. Бодалева, І. Звєрєвої, А. Капської, І. Кона, Г. Лактіонової, А. Мудрика й ін.

Серед науковців, які, на нашу думку, додали фундаментальних наукових знань у досліджувану нами проблему, - В. Бочарова, Т. Василькова, Ю. Василькова, Л. Ваховський, М. Галагузова, Ю. Гапон, Н. Голованова, Н. Заверико, Н. Лавриченко, С. Савченко та ін.

Слушною $є$ думка С. Литвиненко, що особистість настільки соціально успішна, наскільки вона адаптивна, адже за кожною соціальною роллю стоять певні нормативи, а простір соціальних ролей i соціальних відносин - середовище, у якому особистість адаптується. Отже, людина є суб'єктом соціального розвитку, але вона водночас $є$ й суб'єктом саморозвитку, тому соціалізація відбувається тим успішніше, чим активнішою $\epsilon$ участь людини у творчо-перетворювальній

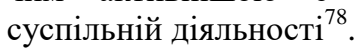

Докторське дослідження С. Савченко показало, що сьогодні соціалізацію варто розглядати як:

77 Лукашевич М.П., Семигіна Т.В. Соціальна робота (теорія і практика) : навчальний посібник. Київ : ІПК ДСЗУ, 2007. С. 320 с.

${ }^{78}$ Литвиненко С.Я., Ямницький В.М. Дитина і середовище: проблеми взаємодії. Оновлення змісту та методів навчання $і$ виховання в закладах освіти : збірник наукових праць. Рівне : РДГУ, 2002. Вип. 22. С. 216-219. 
- багатоскладний і багатофакторний процес набуття індивідом людських властивостей і якостей, спрямованість яких визначається конкретною соціальною ситуацією;

- явище, сутнісні характеристики якого забезпечують суб'єктсуб'єктну єдність особистості, що виражається в одночасному засвоєнні й відтворенні соціальних цінностей і норм;

- соціокультурний феномен, який характеризується незмінністю психологічних механізмів і їх неповторністю в контексті становлення конкретної людської особистості;

- рушійну силу, що активізує процеси самоперетворення, які відбуваються на фоні змін соціокультурного середовища;

- соціально-педагогічне поняття, яке відображає хід соціального формування особистості в конкретному соціокультурному середовищі;

- процес соціальної ідентифікації типу особистості, на відміну від виховання, яке формує внутрішній духовний світ людини;

- невід'ємну частину цілісного навчально-виховного процесу в усіх типах навчальних закладів у системі освіти України ${ }^{79}$.

У докторському дослідженні Т. Кравченко визначено такі основні характеристики процесу соціалізації дітей: адаптація (пристосування людини до соціального середовища й часткове пристосування самого середовища до людини, що забезпечує узгодження взаємних вимог i очікувань); соціальна роль (стереотипізована модель поведінки, яка задається соціальною позицією індивіда в системі соціальних або міжособистісних відносин); соціальний статус (нормативний зразок поведінки в соціальній системі, що охоплює сукупність відповідних прав та обов'язків); соціальні норми (стандарти діяльності й правила поведінки в суспільстві); моральні норми (моральні вимоги до поведінки, які грунтуються на прийнятих у певній культурі поглядах на сутність добра і зла, моральних антиномій); соціальні настановлення (суб'єктивні орієнтації на суспільні цінності); соціальна поведінка (поведінка, що регулюється індивідуальною та суспільною свідомістю, соціальними інститутами, правовими нормами, мораллю); цінності (те, що поціновує особистість); ціннісні орієнтації (усвідомлені й інтеріоризовані соціальні цінності, які відповідають потребам індивіда); соціальна свідомість (відображення соціальної дійсності); соціальний досвід (підсумок попереднього розвитку суспільства, у якому зафіксовані суттєві результати діяльності людей); соціальні відносини (відносини між представниками певних соціальних груп відповідно до того, яке становище кожний з них посідає в соціальній

79 Савченко С.В. Науково-теоретичні засади соціалізації студентської молоді в позанавчальній діяльності в умовах регіонального простору : автореф. дис. ... докт. пед. наук. Луганськ, 2004. С. 50. 
структурі суспільства); фактори соціалізації (сили, умови, що впливають на людину в процесі іiі прилучення до культури певного суспільства); агенти соціалізації (особи, які задають певні параметри уявленням, настановленням індивіда, його ціннісним орієнтаціям); способи соціалізації (конкретні види взаємодії індивіда із середовищем).

Науковцем простежений тісний зв'язок між соціалізацією й вихованням у контексті діяльнісного (самостійне стихійне пізнання дійсності - занурення в спеціально організовані виховні ситуації реальна взаємодія із соціумом) і синергетичного (цілеспрямована підтримка саморозвитку дитини з метою забезпечення здійснення нею суспільно ціннісного вибору в моменти біфуркації) підходів ${ }^{80}$.

Науковець М. Незамай уважає, що запорукою успішної адаптації є оптимальна організація діяльності в закладі дошкільної освіти, який $\epsilon$ важливою ланкою в цьому процесі й головним осередком формування соціальних взаємин, моральних норм, успішної інтеграції, також усуває соціально-психологічну напруженість, стресовий стан, травми ${ }^{81}$.

Ще одним важливим аспектом соціалізації особистості $є$ розвиток соціального інтелекту. Так, на думку В. Куніциної, високий рівень соціального інтелекту свідчить про неабияку соціально-психологічну адаптацію людини до зовнішніх умов навколишнього середовища, що виявляється в здатності здійснювати позитивний вплив на інших ${ }^{82}$.

Низка сучасних психологів: М. Амінов, Ю. Ємельянов, М. Молоканов - уважає, що соціальний інтелект як здатність до соціального пізнання $є$ провідним компонентом готовності індивіда до здійснення професійної діяльності. Спираючись на результати проведених досліджень, Ю. Смельянов зазначає, що сферу можливостей суб'єкт-суб'єктного пізнання індивідами один одного можна назвати соціальним інтелектом, розуміючи під останнім досить стійку здатність розуміти самого себе, а також інших людей, їхніх взаємостосунків, а також прогнозувати плин міжособистісних подій ${ }^{83}$.

${ }^{80}$ Кравченко Т.В. Теоретико-методичні засади соціалізації дітей шкільного віку у взаємодії сім'ї і школи : автореф. дис. ... докт. пед. наук. Київ, 2010. С. 13.

81 Незамай M.I. Адаптація та психолого-педагогічний супровід дітей дошкільного віку 3 внутрішньо переміщених родин. Науковий часопис національного педагогічного університету імені М.П. Драгоманова. Серія «Педагогічні науки: реалії та перспективи». Київ : Вид-во НПУ імені М. П. Драгоманова, 2019. Вип. 69. С. 139-143.

82 Куницына В.Н., Казаринова Н.В. Межличностное общение : учебник для вузов. Санкт-Петербург : Питер, 2002. С. 458.

${ }^{83}$ Емельянов Ю.Н. Активное социально-психологическое обучение. Ленинград : Изд-во Ленингр. ун-та, 1985. С. 85. 
Вагомий внесок у розгляд сутності процесу соціалізації особистості в дошкільному дитинстві здійснено I. Рогальською. Дослідниця тлумачить поняття «соціалізація особистості в дошкільному дитинстві» як процес становлення дитячої особистості в її взаємодії із соціальним світом на основі порівневого входження дитини в систему соціальних зв'язків, активного освоєння соціокультурного досвіду через іiі суб'єктивне пізнання суспільного довкілля та конструювання образу соціального світу» ${ }^{84}$. Специфіка соціалізації особистості в дошкільному дитинстві, на думку вченої, полягає в неперервній зміні простору іiі «соціального дозрівання», у забезпеченні розширення ступеня свободи під час іiі введення в суспільне довкілля, у розвитку іiі суб’єктивної активності й формуванні соціальної компетентності, у соціальноемоційному освоєнні суспільного довкілля й орієнтується на збагачення життя дітей у соціокультурному просторі ${ }^{85}$.

Провідними завданнями соціалізації на етапі дошкільного дитинстві I. Рогальська визначає забезпечення активного пристосування дітей до нових для них соціальних умов життєдіяльності, набуття соціальноемоційної рівноваги та стійкості до впливу змінних умов соціального середовища; розширення і збагачення досвіду конструктивної взаємодії 3 людьми, які їх оточують, на міжособистісному рівні й побудову соціальних стосунків через розвиток способів комунікації, формування уявлень про способи та норми спілкування з довкіллям; розвиток активності, ініціативності, самостійності й відповідальності як базових якостей особистості; залучення дітей у широке суспільне довкілля для формування уявлень про життя людей у соціумі, формування гармонійних стосунків 3 однолітками через організацію взаємодії на рівні емоційного спілкування, вибудовування соціальної поведінки дитини в суспільному довкіллі.

У сучасних наукових дослідженнях, які стосуються соціалізації молодого покоління, процес статево-рольової соціалізації розглядається за такими напрямами: процес засвоєння особистістю статевих стереотипів, цінностей, стандартних мовленнєвих конструктів, жестів, символів, характерних для представників певної статі, формування статевого типу особистості (В. Авраменко, В. Васютинський, К. Веселовська, Т. Говорун, О. Кікінеджі, Д. Колесов); здатність зростаючої особистості орієнтуватися в особливостях поведінки та ролей хлопчиків і дівчаток, керуватися в діях моральними нормами,

84 Рогальська І.П. Теоретико-методичні засади соціалізації особистості у дошкільному дитинстві : автореф. дис. ... докт. пед. наук. Луганськ, 2009. С. 17.

85 Рогальська І.П. Теоретико-методичні засади соціалізації особистості у дошкільному дитинстві : автореф. дис. ... докт. пед. наук. Луганськ, 2009. С. 26. 
цінувати свою статеву належність, налагоджувати гармонійні взаємини 3 оточенням (Я. Коломинський, І. Кон, В. Каган, Д. Ісаєв та ін. ${ }^{86}$.

Нові трансформаційні процеси в нашій державі потребують глибшого осмислення педагогічного супроводу гендерної соціалізації молодого покоління, підтвердження цього знаходимо в дослідженнях Л. Карнаух, В. Кравець, О. Кікінеджі, В. Москаленко, О. Біла, Т. Дороніна та інших, які визначають, що складниками українського гендерного коду $є$ поєднання архетипу Матері, культу жіночого начала як носія духовної культури 3 андроцентричністю характеру та самодостатністю маскулінної поведінки козацтва. Тому відродження ментальності, українських етнотрадицій і впровадження інновацій $є$ важливою умовою ефективності навчання, егалітарного гендерного самовизначення молодих людей ${ }^{87}$.

Гендерна соціалізація $\epsilon$ процесом набуття дітьми статевовідповідних знань, умінь і навичок. Про гендерну соціалізованість дітей свідчать такі прояви поведінки: 1) вибір ігор та іграшок (ігри в ляльки, дочки-матері, лікаря, учительку або у війну, конструктори); 2) рольові переваги під час ігор (хочуть бути матір'ю, учителькою, господинею, медсестрою або командиром, розвідником, батьком); 3) вибір середовища спілкування (надають перевагу групі своєї або протилежної статі, тяжіють до дорослих чоловіків або жінок); 4) вибір видів діяльності (охоче займаються домашніми справами, надають перевагу «тихим» заняттям або виявляють інтерес до техніки, динамічних видів спорту, які вимагають сили, витривалості, агресивності); 5) ставлення до свого зовнішнього вигляду (бажання одягати жіночі речі, використання косметики, красування перед дзеркалом або нехтування зовнішнім виглядом, відмова від прикрас, підсилення чоловічого стилю); 6) фантазії та мрії (бажання бути схожим на літературного або кіногероя певної статі, уявлення себе в майбутньому під час складання оповідань, казок); 7) рівень задоволеності соціальною роллю (захоплення стилем життя чоловіків або жінок, бажання змінити ім'я або навіть стать); 8) стиль поведінки (плавність ходи, м'якість жестикуляції, міміки й тембру голосу або розмашистість, різкість, настирність i незграбність $)^{88}$.

Ми погоджуємося з думкою К. Крутій та О. Фунтіковою, що гендерна соціалізація охоплює дві взаємозалежні сторони: а) привласнення дитиною

86 Поляничко А., Корінна Г. Особливості статево-рольової соціалізації вихованців закладів інтернатного типу. Педагогічні науки: теорія, історія, інноваційні технології. 2018. № 6. С. 120-129.

87 Гендерні стандарти сучасної освіти : збірка рекомендацій. Частина 3. Запоріжжя : Друкарський світ, 2011. С. 10.

${ }^{88}$ Карнаух Л. Педагогічний супровід тендерної соціалізації особистості в період дошкільного дитинства. Вісник Черкаського університету. Серія «Педагогічні науки». 2017. № 5. С. 59-63. 
прийнятих моделей чоловічої та жіночої поведінки, відносин, норм, цінностей і гендерних стереотипів; б) вплив суспільства, соціального середовища на індивіда 3 метою прищеплення йому певних правил $\mathrm{i}$ стандартів поведінки, соціально прийнятих для чоловіків і жінок ${ }^{89}$.

Дослідники розрізняють дві фази гендерної соціалізації: адаптивну (зовнішне пристосування гендерних відносин, норм i ролей) та інтеріоризації (сутнісне засвоєння чоловічих і жіночих ролей, гендерних відносин і цінностей). Тому гендерна соціалізація в період дошкільного дитинства полягає в оволодінні хлопчиком чи дівчинкою нормами статеворольвої поведінки й культурою міжстатевих стосунків.

Соціалізація є надзвичайно важливим процесом, бо саме він визначає рівень адаптивності дитини в подальшому житті. Процес соціалізації дошкільників уважається основною проблемою в дошкільній педагогіці та психології, адже наскільки успішно дитина зможе ії розв'язати, настільки повноцінно ії особистість зможе функціонувати в соціумі. Гармонійність розвитку дитини дошкільного віку залежить від ступеня соціалізації, від засвоєння норм і правил, які необхідні для того, щоб стати повноцінним членом соціального середовища ${ }^{90}$.

Проблема впливу сучасних ЗМІ на свідомість особистості підлітка вивчав Я. Шугайло. Серед негативних наслідків впливу ЗМI на соціалізацію підлітків науковець визначив формування залежності від певного виду ЗМІ (особливу увагу звернемо на мережу Інтернет); формування стереотипів; наслідки впливу сцен насильства в ЗМI; наслідки вПливу реклами; наслідки впливу відверто сексуальних сцен у ЗМІ. Визначені негативні наслідки приводять до порушення пізнавальної функції, звуження кола пізнавальних інтересів підлітків, порушення соціальних контактів, відволікання їх від реального життя, навчання, природних дитячих інтересів та обов'язків, виникнення залежної поведінки в разі надмірного залучення інформації, формування викривлених світоглядних цінностей і настанов, наслідування агресивної, асоціальної поведінки, деформації морального розвитку та схильності до порушення морально-етичних норм ${ }^{91}$.

Показники, що стосуються рис особистості, виділила Л. Барінова: контроль бажань, сила «Я», сила «над Я», які можна інтерпретувати як емоційно-вольові особливості особистості. Виразність зазначених рис

89 Дошкільна освіта : словник-довідник : понад 1000 термінів, понять та назв / упор. К.Л. Крутій, О.О. Фунтікова. Запоріжжя : ТОВ «ЛІПС» ЛТД, 2010. С. 248.

90 Андрейко Б.В., Дмитрів Ю.М. Психологічні особливості соціалізації та спілкування дітей дошкільного віку із загальним недорозвиненим мовленням III рівня. PSYCHOLOGICAL JOURNAL. 2019. № 2 (22). С. 213-226.

91 Шугайло Я.В. Особливості впровадження педагогічної моделі подолання негативного впливу засобів масової інформації на процес соціалізації підлітків. Journal «Science Rise: Pedagogical Education». 2017. № 10 (18). C. 23-28. 
указує на переважання цілеспрямованості й інтегрованості особистості, засвідчує розвиненість самоконтролю, точність виконання соціальних вимог, знання себе, добрий контроль своїх емоцій і поведінки, обов'язковість у дорученнях, звичку доводити справи до кінця. Характеризує витриманість, працездатність, емоційну зрілість, стійкість інтересів, а також указує на усвідомлюваність у дотриманні норм і правил поведінки, наполегливість у досягненні мети, точність і відповідальність, ділову спрямованість ${ }^{92}$.

Отже, сутність соціалізації може бути визначена як процес входження особистості в систему суспільних відносин, результат розвитку особистості як універсального суб'єкта діяльності шляхом його багаторівневої взаємодії із суспільством на підставі формування соціально-типових якостей, які є внутрішніми регулятивами свідомості, поведінки й діяльності.

\section{ВИСНОВКИ}

У дослідженні здійснене теоретичне узагальнення й нове вирішення проблеми соціалізації особистості на різних етапах ії становлення.

Аналіз психолого-педагогічних джерел дослідження проблеми соціалізації особистості показав надзвичайно велику кількість теорій i концепцій соціалізації, загальною властивістю яких є те, що в них зроблені спроби визначення сутнісних характеристик соціалізації, запропоновані підходи до типології й періодизації процесу соціального розвитку особистості, розглянуті особливості соціалізації окремих категорій, соціальних спільнот і вікових груп.

На основі теоретичного аналізу наукової психолого-педагогічної літератури уточнено зміст ключових понять дослідження: «соціалізація», «соціальна адаптація», «соціальний розвиток особистості». Соціалізація - двобічний процес, який містить, з одного боку, засвоєння індивідом соціального досвіду шляхом входження в соціальне середовище, систему соціальних зв'язків; 3 іншого боку, процес активного відтворення індивідом систем соціальних зв'язків за рахунок його активної діяльності, активного включення в соціальне середовище.

Соціальна адаптація - пристосування індивіда до умов соціального середовища, формування адекватної системи відносин із соціальними об’єктами, рольова пластичність поведінки, інтеграція особистості в соціальні групи, діяльність щодо освоєння стабільних соціальних умов, прийняття норм і цінностей нового соціального середовища, форм соціальної взаємодії.

92 Барінова Л. Моделі особистості із різними типами життєвих стратегій. Science and Education. Psychology. 2018. № 3. C. 5-11. 
Соиіальний розвиток особистості - взаємопов'язаний процес соціалізації-індивідуалізації дитини дошкільного віку, який, з одного боку, містить засвоєння соціокультурного досвіду у вигляді правил, норм, способів поведінки, еталонів дії та взаємодії людей у соціумі, а з іншого - розвиває сутнісне «Я» дитини, іiі індивідуальність і неповторність, надає певної автономності й незалежності від соціуму, здатності гармонійно та ефективно адаптуватися до нових умов постійно змінюваного соціального середовища.

Аналіз тлумачень сутності соціалізації, що існують у концепціях і теоріях соціалізації (соціологічна, культурологічна, соціальнопсихологічна, педагогічна концепції), свідчить, що сутнісними ознаками соціалізації $\epsilon$ процес впливу соціального середовища на індивіда, передавання культурного досвіду, адаптація до соціальних умов, цілеспрямоване формування колективістських якостей. Наведені розбіжності певною мірою зумовлені предметною специфікою кожної 3 галузей наукового знання.

\section{АНОТАЦІЯ}

У монографії розглянуто процес «соціалізації» як предмет інтенсивних теоретичних та експериментальних досліджень вітчизняних і зарубіжних учених. Проаналізовано базові поняття дослідження: «соціалізація», «соціальна адаптація», «соціальний розвиток особистості», що дало змогу чітко обгрунтувати теоретичні засади концепцій у визначенні сутності соціалізації, що існує у вітчизняній і зарубіжній науковій літературі, здійснити їх класифікацію за різними ознаками. Філософський підхід до проблеми соціалізації особистості полягає в тому, що соціалізація особистості розглядається як процес взаємодії індивіда й суспільства на основі предметно-перетворювальної діяльності індивіда, наслідком чого стає конкретно-історична форма його соціальності. Представники соціологічної думки визначають соціалізацію як цілісність усіх впливів соціального та культурного середовища, що спонтанно навчають індивіда адаптуватися до структури, зразків поведінки певних конкретних соціальних груп. Культурологічна концепція розглядає соціалізацію 3 позиції засвоєння індивідом культури суспільства, у якому формується й концентрується особистість, засвоєння знань, умінь і навичок, необхідних людині для адекватної діяльності та взаємодії із соціокультурним оточенням. У соціальній психології соціалізація особистості практично ототожнюється із соціальною адаптацією в широкому іiі розумінні. Соціальна адаптація $є$ інтегративним показником стану людини, який віддзеркалює iї можливості виконувати певні біосоціальні функції: адекватне сприйняття соціальної дійсності й власного організму; адекватну систему стосунків 3 довкіллям; спроможність до праці, навчання, організації дозвілля; здатність до самообслуговування та 
взаємообслуговування в сім'ї та колективі; адаптивність поведінки відповідно до рольових очікувань інших.

3'ясовано, що соціальний розвиток особистості - це процес, за якого відбувається засвоєння традицій культури і суспільства, у якому вона росте, формування цінностей. I сім'я як головний та основний його осередок стає своєрідним провідником, який із покоління в покоління несе досвід і знання, накопичені раніше. Саме для того, щоб сприйняття навколишнього світу індивідом згодом не стало спотвореним, батьки створюють у будинку правильну психологічну атмосферу - атмосферу довіри та взаємної поваги.

\section{ЛIТЕРАТУРА}

1. Абульханова-Славская К.А., Брушлинский А.В. Философскопсихологическая концепция С.Л. Рубинштейна: к 100-летию со дня рождения. Москва : Наука, 1989. 248 с.

2. Авраменко О.О. Соціалізація особистості в контексті вітчизняних та зарубіжних науково-педагогічних досліджень. Вісник Черкаського університету. Серія «Педагогічні науки». Черкаси, 2015. № 10 (343). C. 7-13.

3. Авраменко О.О. Проблема міжособистісних взаємин дітей в різновіковій групі дошкільного навчального закладу. Науковий вісник Миколаївського державного педагогічного університету. Спецвипуск «Педагогічні науки» : збірник наукових праць : у 2 т. / гол. ред.: В.Д. Будак, О.М. Пєхота. Миколаїв : МДУ, 2008. 276 с.

4. Авраменко О.О. Проблема соціалізації особистості в дослідженнях зарубіжних вчених. Педагогічна теорія $і$ практика : збірник наукових праць. Київ : КиМУ, 2013. Вип. 4. С. 3-14.

5. Андреева Г.М. Социальная психология. Москва : Аспект-Пресс, 1996. 376 c.

6. Андрейко Б.В., Дмитрів Ю.М. Психологічні особливості соціалізації та спілкування дітей дошкільного віку із загальним недорозвиненим мовленням III рівня. PSYCHOLOGICAL JOURNAL. 2019. № 2 (22). C. 213-226. URL: https://doi.org/10.31108/1.2019.2.22.

7. Асмолов А.Г. Психология личности: Принципы общепсихологического анализа : учебник. Москва : Издательство МГУ, 1990. 367 с.

8. Атаева Р.Д. Педагогические условия социальной адаптации подростков в инновационной гимназии с поликультурной средой : дисс. ... канд. пед. наук. Ставрополь, 2004. 201 с.

9. Барінова Л. Моделі особистості із різними типами життєвих стратегій. Science and Education. Psychology. 2018. № 3. C. 5-11. URL: https://doi.org/10.24195/2414-4665-2018-3-1. 
10. Безпалько О.В. Соціальна педагогіка: схеми, таблиці, коментарі: навчальний посібник для студ. вищ. навч. закл. Київ : Центр учбової літератури, 2009. 208 с.

11. Божович Л.И. Личность и ее формирование в детском возрасте (Психологическое исследование). Москва : Просвещение, 1968. 464 с.

12. Вебер М. О некоторых категориях понимающей социологии. Западноевропейская сочиология XIX-начала XX веков. Москва : Наука, 1996. C. 491-507.

13. Вопросы психологии ребенка дошкольного возраста / под ред. А.Н. Леонтьева, А.В. Запорожца. Москва-Ленинград : Изд-во АПН РСФСР, 1948. $365 \mathrm{c}$.

14. Выготский Л.С. Детская психология : собрание сочинений : в 6 т. / под ред. Д.Б. Эльконина. Москва : Педагогика, 1984. Т 4. 432 с.

15. Выготский Л.С. Мышление и речь: Психологические исследования. Москва : Лабиринт, 1996. 352 с.

16. Гендерні стандарти сучасної освіти: збірка рекомендацій. Частина 3. Запоріжжя : Друкарський світ, 2011. 282 с.

17.Гиддингс Ф.Г. Основания социологии. Ленинград : Наука, $1898.418 \mathrm{c}$.

18. Голованова Н.Ф. Педагогические основы социализации младшего школьника : дисс. ... докт. пед. наук. Санкт-Петербург, 1997. $456 \mathrm{c}$.

19. Гончаренко С.У. Український педагогічний словник. Київ : Либідь, 1997. 373 с.

20. Бочелюк В., Панов М. Діагностика реадаптаційного потенціалу особистості: методологічний аспект. Вісник Харківського національного педагогічного університету імені Г.С. Сковороди. Серія «Психологія». 2019. Вип. 60. С. 8-24. URL: https://doi.org/10.34142/ 23129387.2019. 60.01 .

21. Дошкільна освіта : словник-довідник: понад 1000 термінів, понять та назв / упор. К.Л. Крутій, О.О. Фунтікова. Запоріжжя : ТОВ «ЛІПС» ЛТД, 2010. 324 с.

22. Дюркгейм Е. Метод соціології. Київ ; Харків, 1899. 197 с.

23. Дюркгейм Э. Метод социологии. Западноевропейская социология XIX- начала XX веков. Москва, 1996. С. 256-304.

24. Эльконин Д.Б. Детская психология. Москва : Политиздат, 1960. $363 \mathrm{c}$.

25. Энциклопедический социологический словарь / общ. ред. Г.В. Осипова ; ред.-сост. А.В. Кабыща. Москва : ИСПИРАН, 1995. $939 \mathrm{c}$.

26. Емельянов Ю.Н. Активное социально-психологическое обучение. Ленинград : Изд-во Ленингр. ун-та, 1985. 163 с. 
27. Засєкіна Л.В. Безумовне самоприйняття та психологічне благополуччя особистості. Наука і освіта. 2017. № 11. С. 187-192. URL: https://doi.org/10.24195/2414-4665-2017-11-25.

28. Іонова І.М., Корінна Г. Особливості здійснення соціальнопедагогічного супроводу сім'ї в закладах освіти. Педагогічні науки: теорія, історія, інноваційні технології : науковий журнал / голов. ред. А.А. Сбруєва. Суми : Вид-во СумДПУ імені А.С. Макаренка, 2019. № 6 (90). C. 266-275. URL: 10.24139/2312-5993/2019.06/266-276.

29. Карнаух Л.П.Проблема гендерної соціалізації особистості в зарубіжних та вітчизняних психолого-педагогічних дослідженнях. Науковий вісник Миколаївського державного університету імені В.О Сухомлинського. Серія «Педагогічні науки». 2014. Вип. 1.45. С. 54-59.

30. Карнаух Л. Особливості соціалізації дітей дошкільного віку в умовах сучасного соціального середовища. Психолого-педагогічні проблеми сільської школи. 2012. № 40. С. 110-114.

31. Карнаух Л. Педагогічний супровід тендерної соціалізації особистості в період дошкільного дитинства. Вісник Черкаського університету. Серія «Педагогічні науки». 2017. № 5. С. 59-63.

32. Кислинська Д.М., Мілорадова Н.Е. Цінності та ціннісні орієнтації в психологічних теоріях. Вісник Харківського національного педагогічного університету імені Г.С. Сковороди. Серія «Психологія». 2016. Вип. 53. С. 64-73. URL: dx.doi.org/10.5281/zenodo.44716.

33. Коджаспирова Г.М., Коджаспиров А.Ю. Педагогический словарь для студ. высш. и сред. пед. учеб. заведений. Москва : Академия, 2000. $176 \mathrm{c}$.

34. Кон И. С. Психология ранней юности : книга для учителя. Москва : Просвещение, 1989. 255 с.

35. Кон И.С. Ребенок и общество : учебное пособие для студ. высш. учеб. заведений. Москва : Издательский центр «Академия», 2003. 336 с.

36. Костюк Г.С. Избранные психологические труды. Москва : Педагогика, 1988. 304 с.

37. Котова И.Б., Шиянов Е.Н. Социализация и воспитание. Ростовна-Дону, 1997. 144 с.

38. Кравченко Т.В. Теоретико-методичні засади соціалізації дітей шкільного віку у взаємодії сім’ї і школи : автореф. дис. ... докт. пед. наук. Київ, 2010. 40 с.

39. Кузьмин Е.С. Основы социальной психологии. Ленинград : ЛГУ, 1967. $173 \mathrm{c}$.

40. Куницына В.Н., Казаринова Н.В. Межличностное общение : учебник для вузов. Санкт-Петербург : Питер, 2002. 544 с.

41. Левада Ю.А. Собрание сочинений. Москва : Наука, 1970. 344 с.

42. Левківський М.В. Історія педагогіки : навчальний посібник. Житомир : ЖДПУ, 2002. 292 с. 
43. Левченко T.I. Розвиток освіти та особистості в різних педагогічних системах : монографія. Вінниця : Нова книга, 2002. 512 с.

44. Леонтьев А.Н. Деятельность. Сознание. Личность. 2-е изд. Москва : Политиздат, 1977. 307 с.

45. Лисина М.И. Проблемы онтогенеза общения / Науч.-исслед. ин-т общей и педагогической психологии ; Акад. пед. наук СССР. Москва : Педагогика, 1986. 144 с.

46. Литвиненко С.Я., Ямницький В.М. Дитина i середовище: проблеми взаємодії. Оновлення змісту та методів навчання $і$ виховання в закладах освіти : збірник наукових праць. Рівне : РДГУ, 2002. Вип. 22. С. 216-219.

47. Ломов Б.Ф. Методологические и теоретические проблемы в психологии. Москва : Наука, 1984. 446 с.

48. Лукашевич М.П., Семигіна Т.В. Соціальна робота (теорія і практика) : навчальний посібник. Київ : ІПК ДСЗУ, 2007. 341 с.

49. Марксистско-ленинская диалектика : в 8 кн. Москва : Изд-во Московского ун-та, 1983. Кн. 1 : Материалистическая диалектика как научная система / под ред. проф. А.П. Шептулина. 290-295 с.

50. Марцинковская Т.Д. Диагностика психического развития детей : пособие по практической психологии. Москва : ЛИНКА-ПРЕСС, 1998. $176 \mathrm{c}$.

51. Мертон Р. Социальная структура и аномия. Социология преступности (Современные буржуазные теории) / пер. с франц. Е.А. Самарской ; ред. перев. М.Н. Грецкий. Москва : Прогресс, 1966. C. $299-313$.

52. Москаленко В.В. Социализация личности (философский аспект). Киев : Вища школа, 1986. 200 с.

53. Мудрик А. Социализация человека как проблема. Социальная педагогика. 2005. № 4. С. 47-57.

54. Мудрик А.В. Социальная педагогика : учебное пособие. Москва : Академия, 1999. 184 с.

55. Мухина В.С. Возрастная психология : учебник для студ. высш. учеб. заведений. Москва : Академия, 1997. 432 с.

56. Мухина В.С. К проблеме социального развития ребёнка. Психологический журнал. 1980. Т. 1. № 5.

57. Незамай М.I. Адаптація та психолого-педагогічний супровід дітей дошкільного віку з внутрішньо переміщених родин. Науковий часопис національного педагогічного університету імені М.П. Драгоманова. Серія «Педагогічні науки: реалії та перспективи». Київ : Вид-во НПУ імені М.П. Драгоманова, 2019. Вип. 69. С. 139-143. URL: https://doi.org/10.31392/2311-5491/2019-69.33.

58. Орбан-Лембрик Л.Е. Психологія професійної комунікації : навчальний посібник. Чернівці : Книги XXI, 2010. 528 с. 
59. Павелків Р.В., Цигипало О.П. Дитяча психологія : навчальний посібник. Київ : Академвидав, 2008. 432 с.

60. Парыгин Б.Д. Основы социально-психологической теории. Москва : Мысль, 1971. 351 с.

61. Педагогический энциклопедический словарь / гл. ред. Б.М. БимБад ; ред. кол. : М.М. Безруких, В.А. Болотов, Л.С. Глебова и др. Москва : Большая рос. энциклопедия, 2002. 528 с.

62. Петровский А.В. Проблема развития личности с позиции социальной психологи. Вопросы психологии. 1984. № 4. С. 15-30.

63. Печенко І.П. Дитина в сучасному соціально-педагогічному просторі: проблема захисту прав. Збірник наукових праиь Полтавського державного педагогічного університету ім. В.Г. Короленка. Серія «Педагогічні науки». Полтава, 2005. Вип. 6 (45). С. 45-53.

64. Пихтіна Н.П. Вплив стихійної соціалізації дітей дошкільного віку в умовах неблагополучної сім'ї на виникнення негативних проявів у їхній поведінці. Вісник Глухівського національного педагогічного університету імені Олександра Довженка. Серія «Педагогічні науки». 2018. Вип. 3. С. 104-112. URL: 10.31376/2410-0897-2018-3-38-104-112.

65. Поляничко А., Корінна Г. Особливості статево-рольової соціалізації вихованців закладів інтернатного типу. Педагогічні науки: теорія, історія, інновачійні технологіï. 2018. № 6. С. 120-129. URL: 10.24139/2312-5993/2018.06/120-129.

66. Попова Г.В., Підбуцька Н.В., Богдан Ж.Б. Моделювання соціалізаційних процесів студентства засобами інноваційних психологічних технологій (трансформаційних ігор). Вісник ХНПУ імені Г.С. Сковороди. Серія «Психологія». Вип. I (57). С. 258-281. URL: doi.org/10.5281/zenodo.1184467.

67. Діомідова Н. Просоціальна мотивація як фактор розвитку емоційного інтелекту майбутніх психологів. Вісник ХНПУ імені Г.С. Сковороди. Серія «Психологія». Харків : ХНПУ, 2019. Вип. 51. C. 61-72. URL: http://doi.org/10.5281/zenodo.2527867.

68. Рогальська І.П. Теоретико-методичні засади соціалізації особистості у дошкільному дитинстві : автореф. дис. ... докт. пед. наук. Луганськ, 2009. 43 с.

69. Рогальська-Яблонська І.П., Білик Р.М. Гендерна соціалізація вихованців закладів інтернатного типу: теоретичний аспект питання. Вісник Черкаського університету. Серія «Педагогічні науки». 2018. № 12. C. 109-115. URL: 10.31651/2524-2660-2018-12-109-115.

70. Рогальська-Яблонська I., Рогальська Н. Компетентнісний підхід як основа формування здоров'язбережувальної компетентності дітей дошкільного віку. Вісник Черкаського університету. Серія «Педагогічні науки». 2018. № 10-11. С. 73-79. URL: 10.31651/25242660-2018-10-11-73-79. 
71. Рожков М.Й. Концепция социализации ребенка в работе детских организаций. Москва : Академия, 1991. 87 с.

72. Савченко С.В. Науково-теоретичні засади соціалізації студентської молоді в позанавчальній діяльності в умовах регіонального простору : автореф. дис. ... докт. пед. наук. Луганськ, 2004. 61 с.

73. Словарь социального педагога и социального работника / под ред. И.И. Калачевой, Я.Л. Коломинского, А.И. Левко. 2-е изд. Минск : БелЭн, 2003. 256 с.

74. Смелзер Н. Социология : учебное пособие / пер. с англ. Москва : Феникс, 1998. С. 298-300.

75. Смирнова Е.О. Соотношение межличностных отношений в раннем онтогенезе. Вопросы психологии. 1994. № 6. С. 5-15.

76. Сорокин П.А. Социокультурная динамика и эволюционизм. Американская сочиологическая мысль. Москва, 1996. С. 372-392.

77. Лукашевич М.П. Соціалізація. Виховні механізми і технології : навчально-методичний посібник. Київ : ІЗМН, 1998. 112 с.

78. Соціологія : навчальний посібник для студ. вищ. навч. закладів / за заг. ред. В.І. Докаша. 2-ге вид., доопр., доп. Чернівці : Чернівецький нац. ун-т, 2012. 448 с.

79. Соціологія: терміни, поняття, персоналії : навчальний словникдовідник / уклад. : В.М. Піча, Ю.В. Піча, Н.М. Хома та ін. ; за заг. ред. В.М. Піча. Київ : Каравела; Львів : Новий Світ-2000, 2002. 480 с.

80. Соціальна педагогіка : підручник / за ред. А. Капської. Київ : Центр навчальної літератури, 2003. 256 с.

81. Социализация. Знание. Понимание. Умение. Москва, 2004. № 1. C. $139-143$.

82. Социальное развитие. Краткий словарь по сочиологии / под ред. Д.М. Гришиани, Н.И Лапина; сост. З.М. Коржева, Н.Ф. Наумова. Москва : Политиздат, 1988. С. 272-273.

83. Сухомлинський В.О. Вибрані твори : у 5 т. Київ : Рад. школа, 1976. T. 2. $670 \mathrm{c.}$

84. Соціологія: терміни, поняття, персоналії : навчальний словникдовідник / уклад. : В.М. Піча, Ю.В. Піча, Н.М. Хома та ін. ; за заг. ред. В.М. Піча. Київ : Каравела; Львів : Новий Світ-2000, 2002. 480 с.

85. Тард Г. Социальная логика / пер. с франц. М. Цейтлин. СанктПетербург : Социально-психологический центр, 1996. 554 с.

86. Татьянчикова I., Омельченко М., Татьянчиков А. Психологопедагогічне забезпечення соціалізації учнів 3 інтелектуальними порушеннями. Наука $i$ освіта. 2018. № 5. C. 109-117. URL: https://doi.org/10.24195/2414-4665-2018-5-16).

87. Фельдман Ю.І. Психологія особистості у період молодості. Вісник Харківського національного педагогічного університету імені 
Г.С. Сковороди. Серія «Психологіяџ. 2019. Вип. 57. С. 222-232. URL: doi.org/10.5281/zenodo.888768.

88. Фельдштейн Д.И. Закономерности развития деятельности как основа развития личности : хрестоматия по возрастной психологи : учебное пособие для студентов. Москва, 2006. 304 с.

89. Фрейд 3. «Я» и «Оно». Труды разных лет / сост. А. Григорашвили ; пер. с нем. Тбилиси : Мерани, 1991. Кн. 1. 268-670 с.

90. Парсонс Т. Функциональная теория изменения. Американская социологическая мысль. Москва, 1994. С. 448-464.

91. Циба В.Т. Соціологія особистості: системний підхід (соціальнопсихологічний аналіз) : навчальний посібник. Київ : МАУП, 2000. $152 \mathrm{c}$.

92. Человек и общество (основы современной цивилизации) : учебная хрестоматия для средней школы. Москва : Геликон, 1992. $304 \mathrm{c}$.

93. Черняк С.Г. Зарубіжні та вітчизняні концепції виховання особистості : (теоретичний аналіз). Наука і освіта. 2017. № 2. С. 25-32. URL: https://doi.org/10.24195/2414-4665-2017-2-5.

94.Шугайло Я.В. Особливості впровадження педагогічної моделі подолання негативного впливу засобів масової інформації на процес соціалізації підлітків. Journal «Science Rise: Pedagogical Education». 2017. № 10 (18). C. 23-28. URL: 10.15587/2519-4984.2017.112992.

95. Эльконин Д.Б. Детская психология. Москва : Политиздат, 1960. $363 \mathrm{c}$.

96. Энциклопедический социологический словарь / общ. ред. Г.В. Осипова ; ред.-сост. А.В. Кабыща. Москва : ИСПИ РАН, 1995. $939 \mathrm{c}$.

97. Giddings G. The Theory of Socialization. 1897. № 8. P. 20-22.

98. Role Theory: Concepts and Research / ed. by Biddle B.J. \& Thomas E.J. Hungtington (N.J.) : Krieger, 1979. 45-50 p.

\section{Information about the authors: Avramenko O. O.,}

Candidate of Pedagogical Sciences, Department of Psychology and Pedagogy of Child Development of Pavlo Tychyna Uman State Pedagogical University 2, Sadova Str., Uman, Ukraine, 20300

Kravchuk N. P.,

Candidate of Pedagogical Sciences, Department of Psychology and Pedagogy of Child Development of Pavlo Tychyna Uman State Pedagogical University

2, Sadova Str., Uman, Ukraine, 20300 